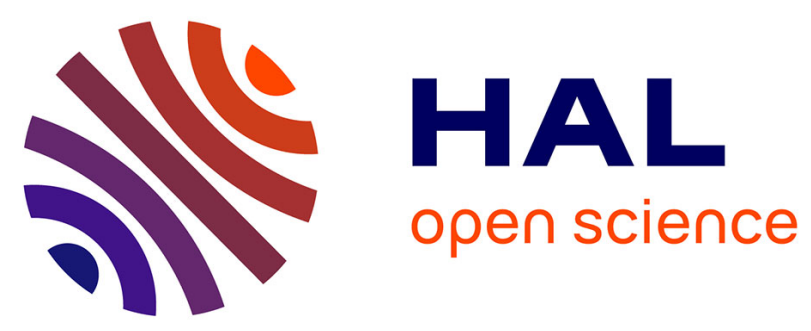

\title{
The volcaniclastic series from the luang prabang basin, Laos: A witness of a triassic magmatic arc?
}

Camille Rossignol, Sylvie Bourquin, Marc Poujol, Erwan Hallot, Marie-Pierre Dabard, Thierry Nalpas

\section{- To cite this version:}

Camille Rossignol, Sylvie Bourquin, Marc Poujol, Erwan Hallot, Marie-Pierre Dabard, et al.. The volcaniclastic series from the luang prabang basin, Laos: A witness of a triassic magmatic arc?. Journal of Asian Earth Sciences, 2016, 120, pp.159-183. 10.1016/j.jseaes.2016.02.001 insu-01267172

\section{HAL Id: insu-01267172 \\ https://hal-insu.archives-ouvertes.fr/insu-01267172}

Submitted on 4 Feb 2016

HAL is a multi-disciplinary open access archive for the deposit and dissemination of scientific research documents, whether they are published or not. The documents may come from teaching and research institutions in France or abroad, or from public or private research centers.
L'archive ouverte pluridisciplinaire HAL, est destinée au dépôt et à la diffusion de documents scientifiques de niveau recherche, publiés ou non, émanant des établissements d'enseignement et de recherche français ou étrangers, des laboratoires publics ou privés. 


\section{THE VOLCANICLASTIC SERIES FROM THE LUANG PRABANG}

\section{BASIN, LAOS: A WITNESS OF A TRIASSIC MAGMATIC ARC?}

Camille Rossignola,b,*, Sylvie Bourquina, Marc Poujola, Erwan Hallota, Marie-Pierre Dabarda, Thierry Nalpas ${ }^{\mathrm{a}}$.

aGéosciences Rennes, UMR CNRS 6118, Université de Rennes 1, OSUR, Campus de Beaulieu, 263 Avenue Leclerc, 35042 Rennes Cedex, France

${ }^{b}$ GéoHydrosystèmes Continentaux, EA 6293, Université François Rabelais, Tours, Campus de Grandmont, 30 Avenue Monge, 37200 Tours, France

camil.rossignol@gmail.com

sylvie.bourquin@univ-rennes1.fr

marc.poujol@univ-rennes1.fr

erwan.hallot@univ-rennes1.fr

marie-pierre.dabard@univ-rennes1.fr

thierry.nalpas@univ-rennes1.fr

*Corresponding author: Camille ROSSIGNOL

Géosciences Rennes, UMR CNRS 6118, Université de Rennes 1, OSUR, Campus de Beaulieu, 35042 Rennes Cedex, France

Bât. 15, Bur. 207/2 
Tel.: +33223236429/+33247367005

Email: camil.rossignol@gmail.com

\section{Abstract}

The paleogeographic evolution of South East Asia (SEA) during the early Mesozoic is still poorly understood and a number of models have recently been put forward to account for the geodynamic evolution of SEA. The Luang Prabang Basin (north Laos), located in the core of a "paleogeographic jigsaw" in SEA, recorded a long lasting volcanism that spanned for $\sim 35$ my from the earliest Triassic up to Late Triassic as evidenced by combined stratigraphic and geochronological (U-Pb/zircon) analyses performed on both volcanic and volcaniclastic series. The volcanic rocks are arc tholeiites and calk-alkaline andesites to dacites. The volcaniclastic rocks contain, in part, volcaniclasts produced contemporaneously with sedimentation. Both the volcanic and volcaniclastic series display geochemical features characteristic of a subduction related volcanism. Therefore, the Luang Prabang Basin documents a magmatic arc in a good agreement with the recent recognition of neighboring ophiolitic rocks in the Luang Prabang area. Following a passive margin setting that prevailed from the late Carboniferous to the late Permian, an active margin then initiated along the western margin of the Indochina Block. This active magmatic arc developed as the result of an east-dipping subduction below the Indochina Block during most of the Triassic, at least from ca. 250 to 215 Ma. Subsequently, this oceanic subduction episode must have been followed by a continental collision of the Indochina Block with the eastern Simao Block, at a period that remains to be defined. 


\section{Keywords}

Indochina

Simao

Nan Uttaradit Suture

Paleotethys

Volcaniclastic sediments

Triassic

\section{Introduction}

The present day South East Asia (SEA) largely results from collisions between several continental blocks (e.g., the Sibumasu, Simao, Indochina and South China blocks, Fig. 1A) and volcanic arcs (e.g., Sukhothai arc, Fig. 1A) during the Triassic and Jurassic periods (e.g., Barr et al., 2006; Mitchell et al., 2012; Peng T. et al., 2013; Zaw et al., 2014; Burrett et al., 2014; Lai C.-K. et al., 2014a and references therein). The exact number of continental fragments and volcanic arcs that actually compose SEA, as well as the timing of their amalgamation, are still controversial and a number of geodynamic models have been proposed to account for the tectonic evolution of the east Tethyan domain (e.g., Ridd, 1971; Burrett, 1974; Sengör, 1979; Mitchell, 1981; Helmcke, 1985; Metcalfe, 1988, 2002; Lepvrier et al., 2004; Ferrari et al., 2008; Carter and Clift, 2008; Cai J.-X. and Zhang K.-J., 2009; Metcalfe, 2011; Liu J. et al., 2012; Cocks and Torsvik, 2013; Lai C.-K. et al., 2014b; Qian X. et al., 2015a). Corollary to these uncertainties about the geodynamic evolution of SEA from the late Paleozoic to the early Mesozoic, the spatial configuration (i.e., the shape) of the blocks that compose the east Tethyan domain and the nature of their boundaries are not precisely known (e.g., Heppe et al., 2007; Wang Q. et al., 2014). 
Despite the fact that the Simao Block encompasses a relatively large geographic area with a triangular shape in south China (western Yunnan) and northern Laos (Fig. 1A), its paleogeographic affinity is poorly constrained. This block was initially recognized by $\mathrm{Wu} \mathrm{H}$. et al. (1995), and is sometimes considered as an independent continental block prior to the Late Triassic (e.g., Wu H. et al., 1995; Metcalfe, 2002; Wakita and Metcalfe, 2005). For instance, Kamvong et al. (2014) suggested that the Simao plate was independent before it collided with, and was integrated into, the eastern Indochina Block during the late Carboniferous. Contradictorily with the existence of this independent plate, the Simao Block is sometimes considered as belonging to the Indochina Block (e.g., Ferrari et al., 2008; Wang Q. et al., 2014), while Sone and Metcalfe (2008) considered it as a "semi-detached portion" of the Indochina Block. Another hypothesis by Barr et al. (2006), reasserted by Qian X. et al. (2015a), postulates that the Simao Block was part of a larger continental unit (called the Sukhothai Block by Barr et al., 2006) that includes both the Simao and the Sukhothai blocks, as depicted on Fig. 1 A.

Central to the question of the paleogeographic affinity of the Simao Block is the actual nature of the mafic rocks cropping out along the Dien Bien Phu Fault (DBPF; Fig. 1B), in the vicinity of which are located the possible eastern and western margins of the Simao and Indochina blocks, respectively. Indeed, the estimated cumulated dextral offset along the Dien Bien Phu Fault (ca. 40 km, Roger et al., 2014) is largely insufficient to explain the occurrence of mafic rocks along the fault by a simple transposition from the Ailaoshan Suture to the NW and/or from the Nan Uttaradit Suture Zone to the SE (i.e., the line approximately located in between the cities of Nan and Uttaradit, Fig. 1B). Therefore, some of the mafic rocks cropping out along the Dien Bien Phu Fault could correspond to a suture zone, which was previously called "Nan Uttaradit - Luang 
Prabang" and "Nan Uttaradit Luang Prabang Dien Bien Phu" by Hutchison (1975) and Wu H. et al. (1995), respectively. However, this potential suture zone did not receive the attention it deserves until recently, as Qian X. et al. (2015a) studied some mafic rocks cropping out ca. $35 \mathrm{~km}$ to the northeast of Luang Prabang. Their investigations lead them to infer a back-arc setting in northwest Laos during the late Carboniferous.

Some other mafic and felsic volcanic and volcaniclastic rocks have been documented in the Luang Prabang Basin (e.g., Bercovici et al., 2012; Blanchard et al., 2013, Fig. 2). However, the geodynamical significance of these rocks, as well as their relationships with the mafic rocks described by Qian X. et al. (2015a) as representative of late Carboniferous back-arc basins, are unknown, thus motivating the present work. Based on a petro-geochemical and geochronological study of the volcanic and volcaniclastic rocks from the Luang Prabang Basin, and a comparison of the results with those from Qian X. et al. (2015a), a geodynamical model for the northeast Indochina Block during the Triassic is proposed.

\section{Geological setting}

\subsection{Regional setting}

The blocks that compose the present-day SEA are delimited by proven (ophiolitic) or inferred suture zones (Fig. 1), corresponding to former continental plate boundaries. Some of these suture zones were reactivated and/or offset by Cenozoic shear zones such as the Dien Bien Phu Fault (Roger et al., 2014), the Mae Ping Fault (e.g., Ridd, 2012) or the Red River Fault (e.g., Faure et al., 2014). 
The Simao Block (as depicted on Fig. 1A) is surrounded by a number of suture zones, some of which are poorly known and/or controversial. To the northeast, the Simao Block is separated from the South China Block by the Ailaoshan Suture (Fig. 1B), which is marked by the occurrence of N-MORB and plagiogranite Devonian to early Carboniferous in age (Jian P. et al., 2009a, b; Lai C.-K. et al., 2014a). The closure of the corresponding oceanic domain occurred during the late Permian to the Early Triassic (Jian P. et al., 2009a, b; Lai C.-K. et al., 2014a, b; Liu H. et al., 2014).

To the southeast, the Simao Block is delimited by the debated "Luang Prabang Suture" (Fig. 1B), commonly described as a part of a larger "Nan Uttaradit Luang Prabang Dien Bien Phu" Suture Zone (Hutchison, 1975; Wu H. et al., 1995). The existence of the Luang Prabang Suture was recently backed up by some new results from Qian X. et al. (2015a) who reported the occurrence of late Carboniferous dolerite $(335.5 \pm 3.3 \mathrm{Ma}, \mathrm{U}-\mathrm{Pb} /$ zircon$)$ with an E-MORB signature and pillow-lava basalt $(304.9 \pm$ 3.9 Ma, U-Pb/zircon) with a N-MORB affinity, ca. $35 \mathrm{~km}$ to the northeast of the city of Luang Prabang (Fig. 1B). This work evidences the presence of an oceanic (or oceaniclike) domain in the vicinity of Luang-Prabang during the late Carboniferous. However the timing of its closure and subsequent collision remain unknown.

West of the city of Simao, mafic rocks with an enriched to transitional MORB affinity, and inferred to represent the remnant of another early Permian oceanic paleolithosphere, have been reported in the Jinghong area (Hennig et al., 2009; Li G. et al., 2012; Fig. 1). However, these mafic rocks have also been interpreted as a component of a bimodal, late orogenic magmatic event (Heppe et al., 2007). Further studies are required to demonstrate that the Jinghong area really corresponds to a suture.

Westward, the Simao Block (or a larger block including the Simao area) is possibly delimited by the less controversial Changning Menglian Suture Zone (e.g., Wu 
H. et al., 1995, Fig. 1). Indeed, the Changning Menglian Suture delineates the paleobiogeographic limit between the Gondwanian and the Cathaysian provinces $(\mathrm{Wu} \mathrm{H}$. et al., 1995; see also Zhang K.-J., 1998 and Wu H. et al., 1998). In addition, it contains early Permian blueschists (Zhang R.Y. et al., 1993; Heppe et al., 2007), dismembered ophiolitic complexes (Wu H. et al., 1995) limiting the Sibumasu Block to the west from an eastern block encompassing the Simao area. As a paleobiogeographic divide, this suture zone is also commonly accepted as representing remnants of the "main branch" of the Paleotethys ocean (e.g., Sone and Metcalfe, 2008). In the area, the Changning Menglian accretionary complex is unconformably overlain by unmetamorphosed Middle Jurassic molassic sediments (Zhang R.Y. et al., 1993), which were possibly deposited after a collision, even though the precise age of these molassic sediments is poorly constrained.

In addition to the suture zones delimiting the Simao Block (as depicted on Fig. 1A or as originally defined by $\mathrm{Wu} \mathrm{H}$. et al., 1995), numerous other suture zones have been described in SEA. The Indochina and the South China blocks are delimited by the Song Ma Suture (Fig. 1), represented by a ribbon of ultramafic and mafic rocks displaying a MORB affinity. As for the Ailaoshan Suture, these rocks are Devonian to Carboniferous in age (e.g., Trung et al., 2006; Vuong et al., 2013; Zhang R.Y. et al., 2013, 2014). However here, the timing of the oceanic closure and subsequent collision between the South China and the Indochina blocks is controversial. Carter and Clift (2008) argue for a collision during the Silurian while Liu J. et al. (2012) postulate that the collision took place during the Late Triassic. Various intermediate ages have also been proposed (i.e., early Carboniferous, Metcalfe, 2011; late Permian, Halpin et al., 2015; Early Triassic, Lepvrier et al., 2008; Kamvong et al., 2014, and Middle Triassic, Zhang R.Y. et al., 2013; 
Faure et al., 2014). Recent investigations (Zhang R.Y. et al., 2013; Faure et al., 2014 and references therein) evidenced a high-pressure, low-temperature metamorphic event during the Middle Triassic (Fig. 1B), which is interpreted as the result of the collision between the South China and Indochina blocks, following a south- (e.g., Zhang R.Y. et al., 2013; Faure et al., 2014) or a north- (e.g., Nakano et al., 2010) dipping subduction.

To the south, the Nan Uttaradit Suture (Fig. 1) marks the western limit of the Indochina Block. It consists of ultramafic and mafic rocks displaying a supra-subduction zone affinity (Orberger et al., 1995) and high-grade metasedimentary rocks (blueschist facies, Barr and Macdonald, 1987). These mafic rocks are late Carboniferous in age (U$\mathrm{Pb} /$ zircon dates of $311 \pm 10 \mathrm{Ma}$ and $316 \pm 3 \mathrm{Ma}$ obtained on a gabbro and a meta-basalt, respectively, and interpreted as their emplacement age, Yang W. et al., accepted). This suture zone also includes cherts containing early Permian to Middle Triassic (Anisian) radiolarian fauna (Ueno and Hisada, 2001; Saesaengseerung et al., 2008). There is a general consensus about the ophiolitic nature of the Nan Uttaradit Suture Zone, although the age of the oceanic closure (e.g., middle Permian; Hirsch et al., 2006; late Permian; Metcalfe, 2011, Early Triassic; Lepvrier et al., 2004; Middle Triassic; Salam et al., 2014 or Late Triassic; Kamvong et al., 2014) and its extension to the north are still controversial (Fig.1).

Westward, the Inthanon Suture Zone (Fig. 1), also called the "Chiang Rai tectonic line cryptic suture" (e.g., Ridd, 2014), has been proposed to represent the limit between the Sibumasu and the Sukhothai blocks (e.g., Sone and Metcalfe, 2008; Ridd, 2014). To the west of the "Chiang Rai tectonic line cryptic suture", the Inthanon Zone corresponds to the Paleotethys ocean floor material, including seamounts with carbonate caps. This zone is interpreted as an extensive accretionary complex (e.g., Sone and Metcalfe, 2008). Alternatively, the boundary between the Sibumasu and the Sukhothai blocks is possibly 
located further to the west along the Mae Yuam Fault (Fig. 1B), which is considered by Ferrari et al. (2008) as a reactivated suture zone. Indeed the fault also corresponds to the boundary between the Gondwanian and Cathaysian paleobiogeographic provinces (e.g., Ueno and Hisada, 2001). Nevertheless, giving support to the hypothesis of a suture along the Inthanon line, the occurrence of Cathaysian fauna in between the Inthanon line and the Mae Yuam Fault has been interpreted as the result of a westward thrusting of the Sukhothai Block, thus standing in an allochthonous position above the Sibumasu Block (Ridd, 2014).

In addition to the aforementioned sutures, some other structures, sometimes including ultramafic and/or mafic rocks have been reported in SEA. Among these, there is the Loei Suture, located to the west of Vientiane (Fig. 1B). When considered as a real suture, most authors propose that it was closed before the late Permian (Boonsoong et al., 2011; Qian X. et al., 2015b). Ultramafic rocks including peridotite and serpentinite of uncertain age are also reported ca. $50 \mathrm{~km}$ to the east of the Luang Prabang Basin (Geological map of Laos, 1990; Fig. 1B) but to our knowledge, these rocks have never been described nor characterized.

Several hypotheses concerning the lateral extension of the ophiolitic segments (dashed lines on Fig. 1) have been proposed in order to correlate assorted ophiolitic segments together and to localize the block boundaries (circled numbers, Fig. 1B). Particularly, the continuity of the Inthanon and Nan Uttaradit sutures toward the north have been hindered by the paucity of data in the concerned areas of Myanmar and Laos. Therefore, depending on the authors, the Inthanon Suture may correlate either with the Changning Menglian Suture (1, Fig. 1B), based on comparisons of the stratigraphic sequences (Sone and Metcalfe, 2008), or with the Jinghong Suture (2, Fig. 1B), based on 
correlations of the interbedded volcanic series (Barr et al., 2006) or from general tectonic and stratigraphic considerations (Ridd, 2014).

Similarly, and relying on stratigraphic considerations, Sone and Metcalfe (2008) correlate the Nan Uttaradit Suture with the Jinghong Suture (3, Fig. 1B) while Feng Q. et al. (2005) correlate it with the Ailaoshan Suture (4, Fig. 1B). Barr et al. (2006) reached a similar conclusion as Feng Q. et al. (2005), derived from the comparison of volcanic series in northern Thailand and Yunnan. In this case, the Dien Bien Phu Fault possibly overprints a potential suture trace (4, Fig. 1B) that is referred to as the "Nan UttaraditLuang Prabang Suture" (Hutchison, 1975), because the estimated dextral offset along this fault (ca. $40 \mathrm{~km}$, Roger et al., 2014) is largely insufficient to account for the offset of the Ailaoshan Suture up to the Nan Uttaradit Suture. The existence of the Luang Prabang Suture recently received some support from the description of mafic rocks displaying a N-MORB affinity along the Dien Bien Phu Fault, ca. $35 \mathrm{~km}$ to the northeast of Luang Prabang (Qian X. et al., 2015a, Fig. 1).

In addition to the uncertainties on the exact positions of the limits of the blocks, there are also contrasted opinions on the timing of the subductions and subsequent collisions that are inferred along these different suture zones. The east Tethyan domain comprises a large number of Permian to Lower Jurassic magmatic rocks (Fig. 1B), among which calk-alkaline volcanic and plutonic rocks are predominant. Depending on the interpretations deduced from these rocks, different timings might be discussed. Notably, the rocks belonging to the (high-K) calk-alkaline suites are subjected to different and somewhat contradictory interpretations. Indeed, the same rocks can be interpreted as emplaced either in a subduction or in a late orogenic setting. For instance, Barr et al. (2006) interpreted the calk-alkaline volcanic rocks cropping out between the 
Nan-Uttaradit and the Inthanon sutures as subduction related, while Srichan et al. (2009), using the coeval occurrence of continental sedimentation, postulated a postcollisional setting for the same calk-alkaline volcanism. Elsewhere, the stratigraphic position of the magmatic rocks with respect to the regional unconformities has also been used to discuss the tectonic settings (e.g., Wang Y. et al., 2010; Peng T. et al., 2013; Liu H. et al., 2014; Wang B. et al., 2014). Nevertheless, the ages of the unconformities are often poorly constrained in SEA. Two to three major regional unconformities are known in northern Thailand (Stokes et al., 1996; Lovatt Smith and Stokes, 1997; Racey, 2009) and Yunnan (Feng et al., 2005) during the upper Permian to the Middle Triassic, the Upper Triassic and the Lower to Middle Jurassic.

\subsection{Geological outline of the Luang Prabang Basin}

The Luang Prabang Basin, originally studied by Counillon (1896, see also Steyer, 2009 and references therein), has been recently investigated for depositional environments (Bercovici et al., 2012; Blanchard et al., 2013), geochronology (Blanchard et al., 2013) and paleontological remains (flora: Bercovici et al., 2012; and fauna: Battail, 2009; Blanchard et al., 2013). A brief outline of these recent results is provided in Table 1.

Structurally, the Luang Prabang Basin (Fig. 2) consists of an asymmetric NE-SW syncline (Blanchard et al., 2013) with a major thrust, possibly superimposed to an unconformity, separating the Purple Claystone (PCS) Formation and the Limestone and Sandstone (LS) Formation to the north from the Red Claystone (RCS) Formation to the south. Internal southeast verging thrusts are documented within the PCS and the LS formations (fms.) and the stratigraphic relationship between these formations is unclear (Fig. 2A; Blanchard et al., 2013). Two hypothesis were kept open by Bercovici et al. 
(2012) and Blanchard et al. (2013): either the PCS Formation (Fm.) is stratigraphically below the LS Fm., or the LS Fm. is stratigraphically overlain by the PCS Fm. (Fig. 2C).

Southward, the Mafic Rocks Unit (MRU), of unknown age, is composed of volcaniclastic rocks and basaltic pillow-lava flows (Blanchard et al., 2013) that were sampled for this work. The MRU is separated from the RCS Fm. to the north by an inferred fault (Fig. 2A, B) and to the south by a reverse fault that constitutes the basal contact of the Luang Prabang nappe (Bush et al., 1996). This nappe, over-thrusting the basin, is composed of polygenic conglomerates including volcanic boulders. Volcanic boulders and volcaniclastic rocks from the Luang Prabang nappe and from the PCS, the RCS and the Luang Prabang Tuffite (LPT) fms. were also sampled for this study to complement those from Blanchard et al. (2013).

\section{Methodology}

\subsection{Geochemistry}

Major and trace element analyses were performed on 18 samples, including 4 volcanic and 8 volcaniclastic samples from the MRU along with 2 boulders of volcanic rocks and 4 volcaniclastic samples from the RCS and the LPT fms. The samples were first crushed in a steel jaw crusher, then separated in two aliquots and grounded in a tungsten or in an agate mill, for major and trace elements analyzes, respectively. The analyses were performed at the SARM laboratory, (CRPG-CNRS, Nancy, France) following the procedure described by Carignan et al. (2001). The powders were digested using lithium metaborate $\left(\mathrm{LiBO}_{2}\right)$ fusion and acid dissolution techniques prior to analyses by Inductively Coupled Plasma - Atomic Emission Spectrometry (ICP-AES) for major 
elements and Sc and by Inductively Coupled Plasma - Mass Spectrometry (ICP-MS) for trace elements. Loss On Ignition (LOI) was determined by heating $1 \mathrm{~g}$ of sample at $1000^{\circ} \mathrm{C}$ and reweighing. Detection limits and analytical uncertainties are given in the Appendix 1.

The composition of magmatic (e.g., Pearce and Cann, 1973) and sedimentary (e.g., Roser and Korsch, 1986) rocks depends upon their tectonic setting, which can be assessed using discrimination diagrams. Discrimination diagrams used in the present study have been established by Verma and Verma (2013) for intermediate magmatic rocks $\left(52 \%<\mathrm{SiO}_{2(\mathrm{adj})} \leq 63 \%\right)$, by Verma et al. (2013) for acid magmatic rocks $\left(\mathrm{SiO}_{2(\mathrm{adj})}>\right.$ 63\%) and by Verma and Armstrong-Altrin (2013) for volcaniclastic rocks. The subscript "adj" refers to an adjustment of the major element contents to $100 \%$ on an anhydrous basis for both magmatic and sedimentary rocks, and using the standard Fe oxidation ratios proposed by Middlemost (1989) for magmatic rocks. The diagrams dedicated to intermediate (Verma and Verma, 2013) and acid (Verma et al., 2013) magmatic rocks are based on discriminant functions using natural logarithm ratios of reputedly relatively immobile trace elements ( $\mathrm{Yb}, \mathrm{La}, \mathrm{Ce}, \mathrm{Sm}, \mathrm{Nb}, \mathrm{Th}, \mathrm{Y}$ and $\mathrm{Zr}$ ). The diagrams dedicated to sedimentary rocks (Verma and Armstrong-Altrin, 2013) are established on a similar approach, but use ratios of major elements including the total iron in the form $\mathrm{Fe}_{2} \mathrm{O}_{3}{ }^{\mathrm{t}}$ (adj) instead of the trace elements. Calculation of the probabilities for a given sets of samples to belong to a given field in these discrimination diagrams were carried out following the methodology described by Verma and Verma (2013). According to these authors, the classification performances of the discrimination diagrams were found relatively unaffected by large $( \pm 20 \%$ for magmatic rocks and $\pm 40 \%$ for sedimentary rocks, respectively) post emplacement compositional changes (e.g., by weathering) making these diagrams of particular interest for weathered rocks. 
All these diagrams allow the discrimination of the following tectonic settings: island arc, continental arc (or undifferentiated arc setting in the diagrams for sedimentary rocks), continental rift together with oceanic island (within plate) and collision. The late orogenic setting is absent from these diagrams. As magmatic suites in late orogenic settings may resemble those encountered in subduction related environments, the method is not able to discriminate a late orogenic setting from an arc setting.

\subsection{U-Pb geochronology}

\subsubsection{Analytical methods}

Zircon grains were extracted following a classical mineral separation procedure (e.g., Poujol and Anhaeusser, 2001). Heavy minerals from $<250 \mu \mathrm{m}$ grain size fraction were successively concentrated using a Wilfey table, a Frantz isodynamic magnetic separator and funnel separation in heavy liquids (bromoform then methylene iodide). Zircon grains were then handpicked under a binocular microscope to produce the most representative sampling, with the aim to avoid intentional bias (but see Sláma and Košler, 2012 and Malusà et al., 2013 and references enclosed in these papers). After embedding the grains in an epoxy resin, the pucks were hand grounded to reveal equatorial cross sections. Laser microsampling sites were chosen based on cathodoluminescence (CL) imaging using a Reliotron CL system equipped with a digital color camera.

To conduct in situ isotopic analyses, samples were ablated using an ESI NWR193UC Excimer laser system connected to an Agilent 7700x quadrupole ICP-MS 
instrument located at the Géosciences Rennes laboratory. Detailed operating and instrumental conditions can be found in Ballouard et al. (2015). During the course of the analyses, the signals of ${ }^{204}(\mathrm{~Pb}+\mathrm{Hg}),{ }^{206} \mathrm{~Pb},{ }^{207} \mathrm{~Pb},{ }^{208} \mathrm{~Pb}$, and ${ }^{238} \mathrm{U}$ masses were acquired. No common $\mathrm{Pb}$ correction was applied. The ${ }^{235} \mathrm{U}$ signal was calculated from ${ }^{238} \mathrm{U}$ using the ratio ${ }^{235} \mathrm{U} /{ }^{238} \mathrm{U}=137.88$. Laser spot diameters of 25 to $40 \mu \mathrm{m}$ with repetition rates of 3-4 Hz were used for ablation. Every ten unknown analyses were bracketed by two measurements of primary GJ-1 standard (Jackson et al., 2004), followed by one measurement of secondary 91500 standard (Wiedenbeck et al., 1995), to correct for mass fractionation and bias and to control data reproducibility, respectively (Appendix 2).

\subsubsection{Data filtering, maximum age calculations and detection limits}

A two-step procedure has been applied to derive maximum depositional ages from the volcaniclastic samples. The first step consisted in filtering the data based on their probability of concordance (Ludwig, 1998; Nemchin and Cawood, 2005), calculated using the relevant function in Isoplot/Ex 3.00 (Ludwig, 2012). Decay constant errors were included in this calculation. The use of the probability of concordance instead of the classical percent of concordance (defined as the percent ratio of the ${ }^{206} \mathrm{~Pb} /{ }^{238} \mathrm{U}$ versus the ${ }^{207} \mathrm{~Pb} /{ }^{206} \mathrm{~Pb}$ or ${ }^{207} \mathrm{~Pb} /{ }^{235} \mathrm{U}$ ages) allows to take into account the errors linked to each analysis. It also avoids variable age difference for grains of different ages at a given level of percent of concordance (e.g., $90 \%$ of concordance means that the ${ }^{206} \mathrm{~Pb} /{ }^{238} \mathrm{U}$ and ${ }^{207} \mathrm{~Pb} /{ }^{206} \mathrm{~Pb}$ ages for a $2.0 \mathrm{Ga}$ grain differ by $200 \mathrm{Ma}$ while the difference is only 2 Ma for a 20 Ma grain). Additionally, the use of a percent of concordance may be problematic because of the difficulty in determining reliable ${ }^{206} \mathrm{~Pb} /{ }^{207} \mathrm{~Pb}$ ages, and hence 
degrees of concordance, for young ages. The use of the probability of concordance appears thus to be more convenient to filter the data regarding the drawbacks of percent concordance. The cut-off level applied to filter the data was $10 \%$.

Data having a probability of concordance $\geq 10 \%$ were kept for the second step that consisted in calculating the maximum depositional age using the youngest cluster of at least 3 analyses from 3 different grains overlapping in age at $2 \sigma$ (standard deviation) as proposed by Dickinson and Gehrels (2009) to ensure a statistically robust estimate of the maximum depositional ages. Maximum depositional ages were calculated as the concordia age (Ludwig, 1998) of these youngest clusters using Isoplot/Ex 3.00 (Ludwig, 2012) and are provided with 95\% confidence limits. The MSWD (mean square of weighted deviates) and probabilities associated with the calculation of concordia ages refer both to the concordance and the equivalence of the chosen populations (Ludwig, 1998), unless otherwise mentioned. Errors on calculated ages take into account decay constant errors.

The ages of the volcanic samples have been calculated using the Tuff Zirc algorithm (Ludwig and Mundill, 2002) to minimize the effects of Pb loss. The algorithm isolates the largest cluster of analyses having a probability of fit in age at a higher value than 0.05 and calculates the median age of this cluster. The uncertainties (asymmetric) are provided with a 95\% confidence limit.

To assess whether the filtered data set for each volcaniclastic sample is representative, the detection limits (i.e., the relative proportions, expressed as the percentages of the largest population of zircon grains that are likely to remain undetected at a given confidence level; Andersen, 2005) are provided. Following Andersen (2005), the calculation of the detection limits for a single grain (assuming a random sampling) is given by: 


$$
X_{L}=1-\left(1-p_{L}\right)^{1 / n}
$$

where $p_{L}$ is the probability level assigned to the detection limit $X_{L}$, and $n$ the number of zircon grains displaying a probability of concordance $\geq 10 \%$. However, as at least 3 grains are required to define a maximum depositional age following the criteria of Dickinson and Gehrels (2009), the threshold value of $X_{L}$ is implicitly defined by the following:

$$
p_{L}=1-\left(\sum_{k=0}^{2}\left(\begin{array}{l}
n \\
k
\end{array}\right) \times\left(1-X_{L}\right)^{n-k} \times X_{L}^{k}\right)
$$

where $k$ ranges between 0 and 2 to subtract, to the total space of probability, the chance to find not any grain $(k=0)$, only 1 grain $(k=1)$ and 2 grains $(k=2)$ belonging to a poorly represented population that would fall below the 3 grains criterion aforementioned.

Developing Eq. (2) we have:

$$
\begin{aligned}
p_{L}=1-(1 & \left.-X_{L}\right)^{n}-n \times\left(1-X_{L}\right)^{n-1} \times X_{L}-\frac{n \times(n-1)}{2} \times\left(1-X_{L}\right)^{n-2} \\
& \times X_{L}^{2}
\end{aligned}
$$

Eq. (3) cannot be solved analytically but a solution can nevertheless be approximated.

A comparison of the detection limits and the maximum depositional ages obtained following the aforementioned procedure with the classical filtering procedure based on percent of concordance $\left({ }^{206} \mathrm{~Pb} /{ }^{238} \mathrm{U}\right.$ versus ${ }^{207} \mathrm{~Pb} /{ }^{206} \mathrm{~Pb}$ ages, cut-off level at 100 $\pm 10 \%$ ) is given in the Appendix 2 .

\section{Petrography and geochemistry}

We focus here on the petro-geochemistry of the MRU, as well as on volcanic boulders and sediments forming part of the Luang Prabang nappe. The petrography of the 
volcaniclastic rocks of the PCS, the RCS and the LPT fms. have already been described in Bercovici et al. (2012) and Blanchard et al. (2013). This work mostly adds geochemical information for the samples from these formations. Petrographic descriptions of all the samples used in this work are provided in Table 2.

The terminology that is used in this work for volcaniclastic rocks partly follows the recommendations of Le Maitre et al. (2002, after Schmid, 1981) for pyroclastic and mixed pyroclastic-epiclastic deposits. However, we choose to use the term "volcaniclast" defined as any rock fragment or individual crystal of volcanic origin independently from any genetic consideration. Indeed, according to Le Maitre et al. (2002), a "pyroclast" is a particle that has not been reworked but, as it is often difficult to distinguish unreworked from reworked volcaniclasts, the strict application of Le Maitre et al. (2002)'s nomenclature is difficult.

\subsection{Mafic Rock Unit (MRU)}

From south to north, the MRU is composed of basaltic flows showing internal pillowlavas (Fig. 3A) implying a subaqueous emplacement, massive lava flows (or intrusions) with no internal structure, and volcaniclastic accumulations, the layers of which are rich in mafic volcaniclasts.

\subsubsection{Volcanic rocks}

The southern basalts (samples LP 22 to LP 24) are porphyritic. They are characterized by plagioclase and zoned clinopyroxene (augite displaying sometimes typical sector twinning; Fig. 3B, C) phenocrysts embedded in a destabilized glassy to microcrolitic groundmass containing plagioclase microcrysts (Fig. 3B) or microlites (Fig. 3C), opaque 
mineral and clinopyroxene microcrysts. The samples display secondary cryptocrystaline to polycrystalline quartz veins and scattered xenomorphic spots, up to a millimeter in size, that also include chlorite and carbonate (calcite).

Collected immediately to the north of the basaltic outcrops, sample LP 25 is a porphyritic microgabbro, also mostly constituted by plagioclase, augite and subhedral opaque minerals (Fig. 3D). One difference with the basalts concerns the quartz that is more abundant, and which mostly occurs as monocrystalline xenomorphic crystals containing apatite needle inclusions. This suggests that part of the quartz in this rock is primary. Cross-cutting veins filled up by polycrystalline secondary quartz are also present (Fig. 3D).

The 4 volcanic samples from the MRU (LP 22 to LP 25) have been analyzed for major and trace elements (Appendix 3). These rocks plot as basalt and basaltic andesite in the total alkali versus silica diagram (TAS; Le Maitre et al., 2002), except sample LP 25 that plots as a trachyandesite (Fig. 4A). The basaltic rocks are sub-alkaline $(0.08<\mathrm{Nb} / \mathrm{Y}$ $<0.16)$. The LOI for all samples but for sample LP 25 are however higher than the maximal value recommended for the use of the TAS diagram (i.e., above 2.5 wt.\%). Using the classification diagram of Winchester and Floyd (1977), based on the relatively immobile trace elements $\mathrm{Nb}, \mathrm{Y}$ and $\mathrm{TiO}_{2}$, we obtain consistent results for all the samples that plot as basalt or andesite (Fig. 4B). This suggests that sample LP 25, although slightly more differentiated than the basalts (i.e., richer in silica and primary quartz), has a particular location in the TAS diagram and could have been enriched in alkaline elements during fluid circulation.

The chondrite normalized patterns of Rare Earth Elements (REE) and Y (Fig. 5A) show a moderate REE enrichment with a slight light REE (LREE) fractionation relative to heavy REE (HREE): (La/Yb) $)_{\mathrm{N}}$ ranges between 1.7 and 2.7 and $(\mathrm{Gd} / \mathrm{Yb})_{\mathrm{N}}$ ranges between 
1.2 and 1.4. The absence of Eu anomaly (Eu/Eu* comprised between 0.96 and 1.03) suggests either that plagioclase was not extracted from the primary magma during differentiation or that the primary magma was oxidizing (Drake and Weill, 1975). Multielement patterns normalized to primitive mantle show significant negative anomalies for $\mathrm{Nb}$ and $\mathrm{Ta}$ with respect to neighboring $\mathrm{U}$ and La elements (Fig. 5B). These negative anomalies in mafic rocks may result from the partial melting of a mantle peridotite enriched in incompatible elements but depleted in $\mathrm{Nb}$ and Ta during selective mantle fertilization by aqueous fluid circulations. Indeed within the mantle, especially above subduction zones, aqueous fluids are likely depleted in $\mathrm{Nb}$ and $\mathrm{Ta}$ owing to the low solubility of these elements while they can be enriched in the other incompatible elements (e.g., Baier et al., 2008). With the exception of sample LP 25, the rocks also display significant positive $\mathrm{Pb}$ and small negative $\mathrm{Ti}$ anomalies (Fig. 5B). The latter possibly results from low-pressure fractional crystallization of opaque minerals (e.g., Briqueu et al., 1984), which is consistent with the presence of sub-euhedral opaque minerals in these basalts (Fig. 3D). The origin of the positive $\mathrm{Pb}$ anomaly in mafic rocks is more ambiguous because it can be generated either by crustal contamination, or by a secondary fluid circulation (e.g., Le Roex et al., 2003). Other anomalies, notably negative for $\mathrm{K}$ and Sr (except for sample LP 25) that are elements known to be highly mobile during alteration processes, will not be discussed any further.

Overall, the geochemical characteristics displayed by the mafic volcanic rocks of the MRU (including the possible intrusive LP 25 sample) are consistent with an arc setting tectonic affinity (Fig. 6) as deduced from discrimination diagrams of Verma and Verma (2013). Indeed, this set of samples presents a relatively high probability $(61.3 \%)$ to belong to an island arc setting. More classical tectonic discrimination diagrams yield similar and consistent results (Appendix 4). 


\subsubsection{Volcaniclastic rocks}

The volcanoclastic rocks of the MRU are tuffaceous arenites. They display various textures, with grain size ranging from fine- to coarse-grained sand (Fig. 3E, F) and a relatively good sorting. These tuffites are composed of volcaniclastic material, comprising both monocrystalline and rock fragments of volcanic origin, and epiclasts in variable proportion. The volcaniclasts are rounded and weathered basaltic rocks fragments, displaying microlithic to trachytic textures (Fig. 3E) that are sometimes porphyritic with greenish clinopyroxene (aegyrine augite?) and/or plagioclase phenocrysts. Isolated individual greenish clinopyroxene or plagioclase crystals or fragments are also common. Additional particles, of epiclastic origin, include rounded siltstone fragments, rounded quartz grains displaying undulatory extinctions and rare carbonate (calcite) grains. Epidote and opaque minerals are also present as individual grains or within the clasts. The matrix, which represents only a small proportion, is mainly constituted by chlorite and calcite.

Eight tuffaceous arenites have been analyzed for major and trace elements (Appendix 3). The REE and Y chondrite normalized patterns of these volcaniclastic rocks (Fig. 5A) show an overall similarity with those of the basaltic rocks of the MRU, but are slightly more enriched in REE and more fractionated with $(\mathrm{La} / \mathrm{Yb})_{\mathrm{N}}$ ranging between 2.4 and 5.2. Selected bivariate diagrams using chemical elements that are known to be immobile (Fig. 7) show that the volcaniclastic rocks define trends from a pole constituted by the volcanic rocks of the MRU. These trends reflect the mixing of volcaniclasts with epiclastic particles. They indicate that the tuffaceous arenites of the 
MRU partly result from the dismantlement of the basaltic rocks similar to those of the MRU and/or are partly formed by pyroclasts made from similar magma compositions.

Consistently with the derivation of the tuffaceous arenites from the basaltic rocks of the MRU type, for which an island arc tectonic setting was inferred (Fig. 6), a very high probability (98.1\%, Fig. 8A) for an arc setting tectonic environment is also obtained for the tuffites when plotted in the tectonic discrimination diagram of Verma and Armstrong-Altrin (2013). The diagram proposed by Roser and Korsch (1986) gives similar results (Appendix 4). Indeed, even if the reliability of this diagram is questionable (e.g., Armstrong-Altrin and Verma, 2005; Ryan and Williams, 2007), the tuffaceous arenites of the MRU all plot, consistently, in the field of the "oceanic island arc margin".

\subsection{Red Claystone (RCS) and the Luang Prabang Tuffite (LPT) formations}

\subsubsection{Volcanic rocks}

The RCS and LPT fms., partly composed of conglomeratic layers, contain rounded felsic volcanic pebbles to boulders, mostly about $10 \mathrm{~cm}$ in size but sometimes up to 30 to 50 $\mathrm{cm}$. The sediments embedded within the Luang Prabang nappe are also conglomeratic and include felsic volcanic boulders. As the overall characteristics of the pebbles and boulders from the RCS and LPT fms. and from the Luang Prabang nappe were found to be similar, they are described together in this section. In doing so, we assume that the conglomerates of the Luang Prabang nappe either include boulders from the RCS and/or the LPT fms. or are lateral equivalents of these formations. Note also that, up to now, felsic volcanic rocks are only known as boulders in the Luang Prabang Basin and nappe. 
The volcanic pebbles and boulders are mainly andesitic, dacitic to rhyolitic when looking at their mineralogical assemblages (Fig. 3G). The boulders display trachytic to microcrystalline and porphyritic textures. They are made up of plagioclase phenocrysts and contain aggregates, which are rich in opaque mineral and pyroxene (?), forming pseudomorphs after hydroxyl-bearing mafic phenocrysts, such as amphibole (hornblende?) and/or biotite (Fig. 3G). Classical in volcanic rocks, such pseudomorphs result from the destabilization of former phases due to pressure drop that enhances the exolution of the volatile elements during magma ascent and subsequent eruption. The dacitic rocks also contain a few corroded quartz crystals (Fig. 3H), which is another classical feature of felsic volcanic rocks that results from changes of the quartz-feldspar thermodynamic stability fields as the pressure drops during magma ascent. Usually the groundmass contains microlites of plagioclase and sanidine that often underline a fluidal texture. Apatite, opaque minerals, allanite and zircon are the classical accessory phases. Silica-rich cryptocrystalline to amorphous cross-cutting veins are rare. The rocks are slightly to significantly weathered, mostly showing sericite that develops from the feldspars, and chlorite and titanite that develop within the opaque mineral-rich pseudomorphs or within the groundmass. Sample LP 70 is more weathered than sample LP 68.

Only two samples, LP 68 (RCS Fm.) and LP 70 (LPT Fm.), were analyzed for geochemistry. In the TAS diagram they plot as trachydacite and rhyolite (Fig. 4A) respectively. Rather consistently, they are classified as andesite and dacite-rhyodacite in the Winchester and Floyd (1977) diagram (Fig. 4B), respectively. They are characterized by a strong enrichment in LREE (Fig. 5A) and to a lesser extent in HREE with respect to the chondrite, with a $(\mathrm{La} / \mathrm{Yb})_{\mathrm{N}}$ of 16.6 for sample LP 68 and 37.1 for sample LP 70. Such a high degree of REE fractionation is compatible with the occurrence of amphibole 
pseudomorphs (Fig. 3G). Sample LP 70 is also marked by a significant negative Ce anomaly $\left(\mathrm{Ce} / \mathrm{Ce}^{*}=0.48\right)$ that may result from various mechanisms including partial melting of a protolith with a negative Ce anomaly, assimilation of marine sediments, post-eruptive contamination by sea water (Bohrson and Reid, 1997), soil formation (Braun et al., 1990, Ndjigui et al., 2009) or post-eruptive meteoric fluid-rock interaction, (Marsh, 1991; Cotten et al., 1995). Because a Y anomaly is lacking in sample LP 70, the negative Ce anomaly is interpreted as the result of alteration due to a post-eruptive hydrothermal or meteoric fluid circulations (e.g., Marsh, 1991; Cotten et al., 1995; Bau, 1996). Multi-elements primitive mantle normalized spectra of these two samples (Fig. 5B) show significant negative anomalies for $\mathrm{Nb}$, $\mathrm{Ta}$ and $\mathrm{Ti}$ and a positive anomaly for $\mathrm{Pb}$, only in the less altered sample LP 68.

The overall geochemical characteristics displayed by the andesitic to dacitic boulders from the RCS and LPT fms. are consistent with an arc setting tectonic affinity. In the tectonic discrimination diagrams of Verma et al. (2013), the probability that these two samples belong to a continental arc setting is $65.1 \%$ (Fig. 9). Consistently, more familiar tectonic discrimination diagrams yield similar results (Appendix 4).

\subsubsection{Volcaniclastic rocks}

The samples of volcaniclastic rocks from the RCS and the LPT fms., tuffaceous arenites to tuffs according to their volcaniclast contents, have already been described in detail by Blanchard et al. (2013). Thus, only short petrographic descriptions of the samples used in this work for chemistry and geochronology are provided in Table 2.

Four tuffaceous arenites have been analyzed for major and trace elements (Appendix 3). The REE and Y chondrite normalized patterns of these rocks (Fig. 5A) 
show an overall similarity with those of the andesitic to dacitic boulders from the conglomeratic layers of the RCS and the LPT fms. They are however slightly less enriched in REE with a $(\mathrm{La} / \mathrm{Yb})_{\mathrm{N}}$ ranging between 10.6 and 17.4. Bivariate diagrams, using immobile elements as variables (Fig. 7), show that these volcaniclastic rocks define trends with a pole constituted by the andesitic to dacitic boulders from the RCS and LPT fms. These trends reflect the mixing of a volcanic source similar to that of the andesitic and dacitic boulders with some epiclastic material. Additionally, both bivariate diagrams and REE spectra show that the volcaniclastic rocks from the MRU and those from the volcaniclastic rocks of the RCS and LPT fms. were fed by distinct volcanic and epiclastic sources.

Consistently with the derivation of these rocks from felsic rocks similar to those represented by the andesitic and dacitic boulders for which a continental arc setting was deduced (Fig. 9), a high probability (73.2\%, Fig. 8B) for an arc setting is also obtained for the volcaniclastic rocks when plotted in the discrimination diagram of Verma and Armstrong-Altrin (2013). In the diagram proposed by Roser and Korsch (1986), the tuffaceous arenites also plot, consistently, in the fields of the "oceanic island arc margin" and "active continental margin" (Appendix 4).

\section{Geochronology}

Fourteen volcanic and volcaniclastic samples were analyzed in order to get new age constraints, complementary to those previously published by Blanchard et al. (2013). The new dating results are presented with emphasis on the Triassic detrital heritage. Older detrital zircon grains were found in most of the analyzed volcaniclastic rocks, but as the data that are older than the Triassic are essentially similar to the one discussed by 
Blanchard et al. (2013), they are not presented here. Analytical results are provided in the supplementary material (Appendix 5).

\subsection{Purple Claystone Formation}

Three tuffaceous arenites (samples LP 03, LP 04 and LP 05) from this formation have been dated. As depicted in Fig. 2C, samples LP 04 and LP 05 are stratigraphically located $65 \mathrm{~m}$ and $130 \mathrm{~m}$ above sample LP 03, respectively. Samples LP 03 and LP 05 come from layers encasing a dicynodont and a chroniosuchian skulls, respectively (Battail, 2009; Bercovici et al., 2012). The taxonomy and phylogenetic analysis of these fossils is beyond the scope of this paper.

Sample LP 03 (Fig. 10B)

One hundred and two zircon grains (105 individual analyses) were analyzed for the tuffaceous arenite sample LP03. Twenty-five zircons grains yielded dates with a probability of concordance $\geq 10 \%$, implying rather low detection limits, ranging between $2.7 \%$ for 1 grain at a probability level of $50 \%$ (noted $\mathrm{DL}_{1(\mathrm{pL}=0.5)}$ ) and $23.2 \%$ for

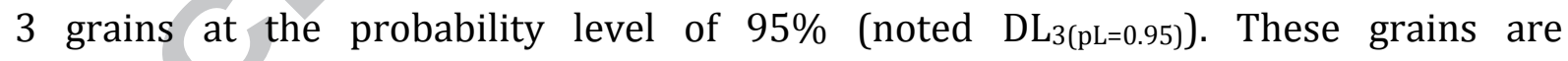
characterized by variably pronounced pinkish colors and variable degrees of roundness. The Th/U ratio for the analyzed zircon grains ranges between 0.24 and 2.09 and most of the grains display well-defined magmatic zoning in cathodoluminescence (CL), suggesting a magmatic origin for all these grains (e.g., Rubatto, 2002).

Six zircon grains, defining the youngest concordant cluster and displaying subrounded to nearly euhedral shapes and a well-defined zoning in CL, give a concordia date of $252.0 \pm 2.6$ Ma with a MSWD of 0.89 and a probability of 0.55 (Fig. 10B). This 
date is interpreted as the maximum depositional age for sample LP 03 (Fig. 10B, Table 3).

Sample LP 04 (Fig. 10C)

A limited number of zircon grains (36) have been extracted from this sample and 41 analyses have been performed. These grains display characteristics that are essentially identical to those observed in sample LP 03, except one grain with $\mathrm{Th} / \mathrm{U}=0.09$, potentially of metamorphic origin (e.g., Rubatto, 2002). Only 7 zircons grains display a probability of concordance $\geq 10 \%$, thus resulting in high detection limits: $\mathrm{DL}_{1(\mathrm{pL}=0.5)}$ is equal to $9.4 \%$ and the $\mathrm{DL}_{3(\mathrm{pL}=0.95)}$ is as high as $65.9 \%$ (Table 2). Given these high detection limits, only the detrital populations that are present in high relative proportions are likely to have been sampled. Conversely, there is a rather high chance that we missed detrital populations with only small relative proportions.

Only one cluster of 4 grains meeting the 3 grains criterion used in this work allows calculating a concordia date of $300.5 \pm 3.7$ Ma $(M S W D=0.73$; probability $=0.65$; Fig. 10C). However, the sample also contains 3 concordant individual grains that are younger, among which the youngest is $251.6 \pm 6.4$ Ma old (MSWD of concordance only $=$ 1.1 ; probability of concordance only $=0.30$ ). Given the high detection limits, it is likely that the youngest population of zircon grains was missed in this sample. As sample LP04 is located $65 \mathrm{~m}$ above sample LP 03, which gives a similar young date within uncertainties, the $251.6 \pm 6.4$ Ma date possibly corresponds to a real geological age rather than an analytical artifact, and is therefore interpreted as the maximum depositional age for sample LP 04 (Table 3).

Sample LP 05 (Fig. 10D) 
Sample LP 05 is a tuffaceous arenite that yielded abundant, sometimes broken, zircon grains displaying rounded to euhedral shapes and variable pinkish colors. The detection limits are fairly low, with a $\mathrm{DL}_{1(\mathrm{pL}=0.5)}$ of $1.8 \%$ and a $\mathrm{DL}_{3(\mathrm{pL}=0.95)}$ of $15.3 \%$ (Table 3 ), ensuring that the main zircon populations have been analyzed. The Th/U of analyzed grains ranges between 0.28 and 1.04 , suggesting a magmatic origin.

A cluster of 21 grains characterized by rounded to euhedral shapes and wellmarked zoning (sometimes disturbed by local resorptions) gives a concordia date of $251.0 \pm 1.4 \mathrm{Ma}(\mathrm{MSWD}=0.55 ;$ probability = 0.99; Fig. 10D), interpreted as the maximum depositional age for this sample. However, 4 independent concordant grains yielded concordia dates of $232.3 \pm 5.9,225.6 \pm 5.6,213.1 \pm 6.1$ and $180.6 \pm 5.0$ Ma (dashed ellipses in Fig. 10D, the latter plotting out of the field shown in the diagram) that do not meet the 3 grains criterion of Dickinson and Gehrels (2009). Accordingly, these younger concordant dates are interpreted as analytical and/or geological artifacts linked to lead losses in the grains.

In summary, the dating of the 3 tuffaceous samples from the PCS Fm. indicates that the sedimentation of these volcaniclastic, braided-river to alluvial plain deposits is Early Triassic or younger. This result contradicts the late Permian age previously attributed to the PCS Fm. on the basis of Dicynodon biostratigraphy (Battail, 2009) and has potential implications on the stratigraphic range of these biostratigraphic markers of the Permian-Triassic boundary. Either the stratigraphic range of Dicynodon should be extended up to the Early Triassic, or the dicynodonts preserved within the PCS Fm. do not belong to the Dicynodon genus. Only a detailed taxonomic analysis of these fossils can provide a final answer between these two alternatives. Ongoing work on the taxonomy and phylogeny of these dicynodonts is nevertheless beyond the scope of this paper. 


\subsection{Mafic Rock Unit}

Several attempts were carried out in order to date the rocks from the MRU. These efforts were unsuccessful for the basaltic rocks and only one tuffaceous arenite (sample LP 42, Fig. 10J) from that Unit yielded enough zircon grains to derive a maximum depositional age (Table 3). Nineteen angular to sub-angular zircon grains displaying various internal structures in CL (oscillatory or patchy zoning, or devoid of any zoning) were analyzed, among which only 3 are concordant. The detection limits are consequently very high, with a $\mathrm{DL}_{1(\mathrm{pL}=0.5)}$ of $15.9 \%$ and a $\mathrm{DL}_{3(\mathrm{pL}=0.95)}$ of $90.3 \%$ (Table 3 ) so that the probability that most of the grain populations have been sampled, is very low. Nevertheless, 3 concordant grains overlapping in age allow to calculate a maximum depositional age of $219.3 \pm 2.9 \mathrm{Ma}$ (concordia date, MSWD = 0.85; probability =0.52; Fig. 10 $)$. Because of the high detection limits, we infer that the population of grains with such a rather young age exhibits a high relative proportion in the sample.

\subsection{Red Claystone and Luang Prabang Tuffite formations}

\subsubsection{Volcanic rocks}

Five andesitic, dacitic to rhyolitic boulders sampled in conglomeratic layers in the RCS Fm. (sample LP 68, Fig. 11A), the LPT Fm. (samples LP 70, 71 and 72, Fig. 11B, 11C and 11D respectively) and in the conglomerates from the Luang Prabang nappe (Fig. 2, sample LP 10, Fig. 11E) have been dated. As for to the petro-chemical results, these samples display similar characteristics regarding their zircon contents, and are presented together. 
Most of the zircon grains have a short prismatic shape and an internal structure typified by well-marked oscillatory zoning. All grains also have Th/U ratios higher than 0.1 , evidencing their magmatic origin.

Plotted in Tera-Wasserburg diagrams, the grains spread along the concordia line (Fig. 11) following the lead loss trends. This spreading is thus interpreted as the consequence of a lead loss suffered by a significant number of grains. To minimize the effect of lead loss on the date calculation, the Tuff Zirc dates were calculated from individual ${ }^{206} \mathrm{~Pb} /{ }^{238} \mathrm{U}$ dates instead of using the weighted ${ }^{206} \mathrm{~Pb} /{ }^{238} \mathrm{U}$ mean date. The obtained Tuff Zirc dates are $217.5+1.7 /-2.4$ for sample LP $68,225.8+1.4 /-2.2$ for sample LP 70, $230.4+0.9 /-1.8$ for sample LP $71,225.4+1.5 /-3.4$ for sample LP 72 and 232.7 +2.8/-1.8 for sample LP 10. They are interpreted as the best estimates for the ages of emplacement for these volcanic rocks. Except in sample LP 10, a few zircon grains yielded significantly older dates, ranging from $251.2 \pm 6.4\left({ }^{206} \mathrm{~Pb} /{ }^{238} \mathrm{U}\right.$ date, sample $\mathrm{LP}$ 70) to $2047.6 \pm 38.8 \mathrm{Ma}\left({ }^{207} \mathrm{~Pb} / 206 \mathrm{~Pb}\right.$ date, sample LP 72$)$. These dates are interpreted as corresponding to the ages of zircon xenocrysts that were incorporated from wall rocks into the intrusive ascending magma feeding the volcanism. These zircon xenocrysts evidence the presence of a substratum made of continental crust by the time the volcanic rocks emplaced, between ca. 233 and ca. 218 Ma.

\subsubsection{Volcaniclastic rocks}

Four tuffaceous arenites and lappilistones (samples LP 06, LP 08, LP 58 and LP 100) from the RCS and LPT fms. have been analyzed in addition to samples LP 44, LP 45 and LP 57 previously dated by Blanchard et al. (2013). In addition, a tuffaceous arenite forming the matrix of the conglomerates from the Luang Prabang nappe (Fig. 2, sample 
LP 11, Fig. 10I) and sharing similar characteristics with the samples from the RCS and LPT fms. regarding its zircon content have been analyzed. These samples are thus presented together.

The precise stratigraphic locations of samples LP 57, LP 58, LP 100, LP 44 and LP 45 are depicted in Fig. 2C, from the base to the top of the log. The exact stratigraphic position of the other samples is not precisely known. Sample LP 100 was encasing a dicynodont skull provisionally identified as a kannemeyeriiform (Blanchard et al., 2013).

\section{Sample LP 58 (Fig. 10E)}

Sample LP 58 comes from the upper part of a grey tuffaceous arenite layer that is interbedded within red silty claystones, where sample LP 57 from Blanchard et al. (2013) was taken. It yielded abundant, sometimes broken, zircon crystals displaying rounded to euhedral shapes, variable pinkish to reddish colors and variable internal structures in CL. The dominant population is composed of zircon grains displaying an elongated, euhedral shape with a slightly pinkish color and a well defined oscillatory zoning, suggesting a magmatic origin. Twenty-four grains out of the 71 analyzed grains are concordant, giving detection limits ranging from $2.8 \%$ for the $\mathrm{DL}_{1(\mathrm{pL}=0.5)}$ to $24.0 \%$ for the $\mathrm{DL}_{3(\mathrm{pL}=0.95)}$ (Table 3).

Among the analyses, the youngest cluster ( 4 grains) gives a concordia date of $224.1 \pm 2.8 \mathrm{Ma}(\mathrm{MSWD}=0.41$; probability $=0.90 ;$ Fig. $10 \mathrm{E})$, which is interpreted as the maximum depositional age for this sample. Within the uncertainties this age is identical with the age obtained from sample LP 57 (224.9 $\pm 1.0 \mathrm{Ma}$; Blanchard et al., 2013). Sample LP 58 also contains 6 concordant grains displaying almost identical shapes, colors and internal structures to those from the youngest cluster, with individual concordia dates ranging from $232.1 \pm 5.7$ Ma to $250.8 \pm 6.7$ Ma. These results are in 
agreement with a hypothesis of continuous volcanic production lasting about 26 my (see discussion). Older dates from the sample are comparable with those obtained in sample LP 57 by Blanchard et al. (2013).

Samples LP 08, LP 06, LP 100 and LP 11 (Fig. 10F, 10G, 10H and 10I, respectively) These samples correspond to tuffaceous arenites, except sample LP 06 which is a lapillistone. They belong to the RCS Fm. (LP 100), the LPT Fm. (LP 08 and LP 06) and a conglomerate from the Luang Prabang nappe (LP 11).

Numerous slightly pinkish, euhedral to sub-rounded zircon grains have been extracted from these volcaniclastic rocks. The grains exhibit well-marked oscillatory zoning with $\mathrm{Th} / \mathrm{U}$ ratios higher than 0.1 (except one grain from sample LP 08), evidencing their magmatic origin. The detection limits for these samples are fairly low, with $\mathrm{DL}_{1(\mathrm{pL}=0.5)}$ and $\mathrm{DL}_{3(\mathrm{pL}=0.95)}$ bracketed between $1.7 \%$ and $2.6 \%$ and $15.0 \%$ and $22.3 \%$, respectively (Table 3), ensuring that the main zircon populations have been analyzed.

Concordia dates calculated from the youngest clusters of these samples are 224.8 \pm 2.9 (sample LP 08; $n=4$, MSWD=0.62, probability=0.74), $222.0 \pm 1.5$ (sample LP 06; $\mathrm{n}=15, \mathrm{MSWD}=0.89$, probability=0.55), $220.9 \pm 1.1$ (sample LP 100; $\mathrm{n}=27, \mathrm{MSWD}=0.62$, probability=0.99) and $220.3 \pm 2.9$ (sample LP 11; n=4, MSWD=1.01, probability=0.42). They are interpreted as the maximum depositional ages of the layers from which the samples were extracted. Two individual concordant analyses give younger concordia dates of 208.7 $\pm 5.9 \mathrm{Ma}$ and 206.7 $\pm 5.5 \mathrm{Ma}$ in sample LP 06 (dashed ellipses in Fig. 10G) that do not fit the Dickinson and Gehrels (2009) 3 grains' criterion. These younger dates are thus interpreted as analytical and/or geological artifacts linked to a slight lead loss in the grains. In addition, a few grains in each sample give older, mainly Proterozoic dates. Nonetheless, most of the concordant analyzed grains have individual dates that 
spread continuously, ranging from ca. $250 \mathrm{Ma}$ down to the individual maximum depositional ages of the samples (Fig. 10F, 10G, 10H, 10I). Again, this suggests that the volcanic production was active over this period. These latter zircon populations were not sampled by Blanchard et al. (2013), who provided maximum depositional ages using far less analyses per sample than in the present work.

In summary, the sedimentation of the rocks from the RCS and LPT fms. occurred during the Norian from ca. $225 \mathrm{Ma}$ to ca. $215 \mathrm{Ma}$, or after. Stratigraphically above these formations, the ML Fm. contains Norian conodonts and ammonites (e.g., Blanchard et al., 2013), which indicates that the RCS and LPT fms. were deposited before the Rhaetian (starting from ca. 208.5 Ma). In addition, no difference was found between the results from the RCS and LPT fms. and those from the conglomerates within the Luang Prabang nappe. This suggests that these conglomerates are possibly lateral equivalents of the RCS and LPT fms. rather than a younger formation.

\section{Discussion}

\subsection{Tectonic setting for the Triassic volcanism}

The prominent geochemical features of both mafic and felsic volcanic rocks documented in the Luang Prabang Basin point to magmas produced in subduction zones (e.g., negative anomalies in $\mathrm{Nb}$, Ta, $\mathrm{Ti}$ and $\mathrm{P}$, positive anomaly in $\mathrm{Pb}$, Fig. 5). Various tectonic discrimination diagrams also suggest an arc setting (oceanic and continental for the mafic and felsic volcanism, respectively, Figs. 6 and 9). Additionally, and wholly consistent with their derivation from the dismantling of volcanic rocks and/or the direct incorporation of mafic or felsic pyroclasts and subsequent mixing with epiclastic 
sources, both the mafic and felsic volcaniclastic rocks point to emplacements in an arc setting (Fig. 8). Magmatic rocks emplaced in late orogenic settings may, however, share very similar characteristics with those emplaced in arc settings (e.g., Hawkesworth et al., 1995; Morris et al., 2000; Srichan et al., 2009). These two contrasted tectonic environments are thus difficult to distinguish from the geochemistry alone. The same statement also holds for the volcaniclastic rocks.

To solve this problem, an argument may be provided considering the duration and the continuity of the volcanic activity. Indeed, a late orogenic setting is commonly characterized by pulsatile, short-lived (generally a few my within a single basin) and bimodal volcanism with gaps in intermediate compositions (e.g., Colgan et al., 2006; Ford et al., 2013) while subduction is usually typified by long-lived magmatic activity, forming a continuous series of mafic to felsic rocks. As already recognized by Blanchard et al. (2013), the maximum depositional ages in the RCS-LPT fms. are younger up the stratigraphic column (Figs. 2C, 10E and 10H), implying syn-sedimentary volcanic activity during the deposition of these formations (Fig. 12). Among all the available dates on these Norian formations, notice, however, that the Tuff Zirc date of sample LP 68 (an andesitic boulder from the RCS Fm.) is younger than the oldest sample from the overlying LPT Fm. Given the spreading of a significant number of analyses following the lead loss trend (Fig. 11A), the Tuff Zirc date of sample LP 68 may confidently be interpreted as the result of lead loss suffered by the zircon grains present in this boulder. The exact age of the solidification of the corresponding volcanic rock is thus unknown and the interpretation of coeval volcanic activity and sedimentation can be maintained.

Contrasting with the syn-sedimentary volcanism documented by the ages in the RCS and LPT fms., maximum depositional ages obtained from the samples of the PCS Fm. 
(Fig. 10B, 10C and 10D) are identical within uncertainties, whatever their stratigraphic position (Fig. 2C). In that case, the uncertainties on the maximum depositional ages and the distance separating the most widely spaced samples (ca. $130 \mathrm{~m}$ between LP 03 and LP 05) do not prove a syn-sedimentary volcanic activity. Similarly, no statement regarding the contemporaneity of the volcanism with the sedimentation can be made for the volcaniclastic rocks of the MRU as only a single sample gave enough zircon grains to be dated.

The dating of volcanic boulders sampled in the conglomeratic layers of the RCS and LPT fms. adds complementary evidence to constrain the duration of the volcanism in the vicinity of the Luang Prabang Basin. The comparison between the oldest age from a reworked volcanic boulder $(232.7+2.8 /-1.8 \mathrm{Ma}$, Fig. 11E) and the youngest maximum depositional age available (215.9 $\pm 1.3 \mathrm{Ma}$, sample LP 45, recalculated after Blanchard et al., 2013, following the procedure adopted in this study for the sake of consistency) shows that the volcanism lasted, at least, ca. 15 my (with a maximum of 20.9 my and a minimum of 13.7 my if we take into account the $2 \sigma$ level uncertainties). Further evidence about the duration of volcanism is finally provided by the large amount of euhedral to angular zircon grains spanning from ca. $250 \mathrm{Ma}$ to the maximum depositional ages of the volcaniclastic samples (Fig. 12C). Therefore, the duration of the volcanism documented in the vicinity of the Luang Prabang Basin is ca. 35 my. In addition, petrographic and field observations point toward a volcanism including intermediate rocks (andesite, dacite) rather than a bimodal volcanism where intermediate compositions are missing or poorly represented. The rather long duration, the continuousness in the production of zircon crystals as well as the overall petrographical and geochemical characteristics of the volcanism documented in the Luang Prabang Basin are therefore more easily explained by its emplacement in a 
subduction setting rather than in a late-orogenic setting. In addition, large extensional structures (e.g. low angle normal fault) commonly observed in late-orogenic extensional settings (e.g., Malavieille, 1993) especially when significant amount of magmas are produced, have not been documented in the Luang Prabang Basin. Also, the marine sedimentation at the end of the Norian, evidenced by the ML Fm. is at odds with the expected continental environment for a late-orogenic setting. The volcanic and volcaniclastic rocks of the Luang Prabang Basin thus reveal the occurrence of an active magmatic arc from the Early to the Late Triassic (at least, from ca. 250 to ca. $215 \mathrm{Ma}$ ) in the vicinity of the basin.

Finally, the mafic volcanic rocks from the MRU display geochemical features that are markedly different from those shown by the late Carboniferous mafic rocks cropping out at ca. $35 \mathrm{~km}$ to the northeast of Luang Prabang (Qian X. et al., 2015a). For instance, the REE patterns displayed by the ca. $305 \mathrm{Ma}$ basaltic pillow-lava are typical of N-MORB affinity, with a $(\mathrm{La} / \mathrm{Yb})_{\mathrm{N}}$ ranging between 0.45 and 0.87 while the $(\mathrm{La} / \mathrm{Yb})_{\mathrm{N}}$ for the basalts from the MRU ranges between 1.74 and 2.66. The REE patterns of the older dolerite (ca. $336 \mathrm{Ma}$ ) samples described by Qian X. et al. (2015a), with a (La/Yb) N $_{\mathrm{N}}$ ratio comprised between 1.55 and 1.77, are similar to those of the MRU (even though slightly lower), but numerous differences are evidenced when considering other major (e.g. $\mathrm{SiO}_{2}$, $\mathrm{TiO}_{2}$ ) and trace elements (e.g. Th, Co). These geochemical differences result in contrasting positions in discrimination diagrams, the late Carboniferous mafic rocks being $\mathrm{N}$ to E-MORB while the basalts of the MRU represent arc tholeiites. Therefore all the mafic rocks cropping out in the Luang Prabang area do not hold an unique geodynamic significance; some represent probable former oceanic crust (ophiolite) while others belong to a former volcanic arc. 


\subsection{Suture zone location and dip of the subduction zone}

The presence of a magmatic arc, attested by the volcanic and volcaniclastic rocks in the Luang Prabang Basin, implies the existence of a destructive plate margin, which was active in the area during, at least, the whole of the Triassic. The existence of late Carboniferous N-MORB cropping out to the northeast of the Luang Prabang Basin (Qian X. et al., 2015a) provides a straightforward explanation for locating this former margin to the west of the Luang Prabang Basin.

The other suture zones (Fig. 1) appear to be far less appealing candidates to represent this former plate margin. Indeed, the Loei Suture zone, located ca. $200 \mathrm{~km}$ to the south of the Luang Prabang Basin (Fig. 1), when described as a suture, is considered as being closed before the late Permian (e.g., Qian X. et al., 2015b). Thus, it cannot account for the Triassic magmatic arc documented in the Luang Prabang Basin. The Song Ma Suture, located to the northeast (Fig. 1) also appears to be an unlikely candidate. Indeed, although the exact timing for the closure of the Song Ma Suture zone is controversial and the collision between the South China and the Indochina blocks could be as young as ca. 230 Ma (Liu J. et al., 2012), most authors proposed an Early to Middle Triassic collision (e.g., Zhang, R.Y. et al., 2013 and Faure et al., 2014 for a recent review). The involvement of a subducting "Song Ma slab" to account for the Norian volcanism evidenced in the Luang Prabang Basin thus appears unlikely.

As a further matter, the present day outcrops that constitute the Nan Uttaradit Suture are located ca. $200 \mathrm{~km}$ southwest of the Luang Prabang Basin. They show the same structural direction as the Luang Prabang syncline and main fault strikes (Fig. 2, Blanchard et al., 2013), as already recognized by Qian X. et al. (2015a). Such structural alignments point to a "Nan Uttaradit - Luang Prabang Suture" as initially proposed by Hutchison (1975) and latter reassessed by Wu H. et al. (1995), Feng Q. et al. (2005), Barr 
et al. (2006) and Qian X. et al. (2015a). Additionally, deep-sea sediments (cherts) that constitute the upper part of the Nan Uttaradit ophiolitic suite range from the early Permian to the Anisian on the basis of radiolarian biostratigraphy (Ueno and Hisada, 2001; Saesaengseerung et al., 2008). Such duration of deep-sea environments is consistent with the occurrence of late Carboniferous N-MORBs and an Early to Late Triassic magmatic arc in the vicinity of the Luang Prabang Basin, giving further support for a "Nan Uttaradit - Luang Prabang Suture". Conversely, the prolongation of the Nan Uttaradit to the Jinghong Suture (e.g., Sone and Metcalfe, 2008; circled number 3 in Fig. 1B) does not follow structural trends displayed by either the Triassic or by the Jurassic structures, thus appearing unlikely. However it does not necessarily mean that the Nan Uttaradit Luang Prabang Suture correlates with the Ailaoshan Suture (e.g., Barr et al., 2006; Qian X. et al., 2015a; circled number 4, Fig. 1B), and the cylindrical view (i.e., the lateral extension of observation made on a limited area), which prevails in most geodynamic interpretations in the area, should be treated with caution. Non-cylindrical interpretations such as the "Mediterranean-style" closure of the Paleotethys ocean with slab rollback, back arc development and subsequent arc closure put forward by Pullen et al. (2008) in central Tibet could also have occurred in the east Tethyan domain.

The location of the Luang Prabang Suture to the west of the Luang Prabang Basin implies an east-dipping subduction. Also, the location of various calk-alkaline magmatic rocks dated from the late Permian to the Late Triassic (Salam et al., 2014; Kamvong et al., 2014; Zaw et al., 2014) that crop out to the east (present day coordinates) of the Nan Uttaradit Suture zone corroborate both an east-dipping subduction zone and a "Nan Uttaradit Luang Prabang Suture”. 


\subsection{Toward a geodynamical evolution model for the Luang Prabang area}

The report of a rather unexpected volcanic arc active up to and during the Late Triassic naturally leads to the proposal of a new geodynamic model for the Luang Prabang area (Fig. 13). The scarcity of available data from northern Laos makes the proposed geodynamic model speculative, but these speculations might in turn constitute a test for the model.

The spreading of oceanic paleolithosphere (Fig. 13A) during the late Carboniferous is attested by the occurrence of N-MORB in northwest Laos (Qian X. et al., 2015a). This oceanic domain was possibly linked, to the south, to the Nan Uttaradit ocean and corresponds to the Paleotethys or, more probably, to a branch of this ocean (Fig. 14A). This oceanic domain isolated the Simao Block from the Indochina Block, forming two independent continental domains. The exact boundary of the western edge of the Simao Block is still an open question: it could correspond to the yet speculative Jinghong Suture Zone (e.g., Heppe et al., 2007; Hennig et al., 2009) or to the unambiguous Changning-Menglian Suture Zone (e.g., Wu H., et al., 1995; Heppe et al., 2007; Sone and Metcalfe, 2008). As the Changning-Menglian Suture Zone appears less controversial than the Jinghong Suture Zone, we favor this working hypothesis (Fig. 14) and follow the initial definition of the Simao Block proposed by Wu H. et al. (1995). To the south, the Changning-Mengliang Suture correlates with the Inthanon Suture (circled number 1 in Fig. 1B). Consequently, we consider - as a working hypothesis - that the Sukhothai arc is part of the Simao Block. The northern continuation of the Simao Block and possible links with the Qiangtang or Qamdo blocks (e.g., Metcalfe, 2011) will no be discussed here. Besides, the southern continuation of the Simao Block and possible links with the Chanthaburi arc terrane (e.g., Metcalfe, 2011) or the Klaeng terrane (e.g., Ridd, 2012) is beyond the scope of this paper. 
The Nan Uttaradit Suture and its prolongation to Luang Prabang are often seen as the remnants of small oceanic basins corresponding to back arc basins that developed coevally with the subduction of the Changning Menglian slab to the west (e.g. Qian X. et al., 2015a). However, two facts are at odds with the view of small back-arc basins. Firstly, this oceanic paleolithosphere persisted from the late Carboniferous up to the Norian (i.e. during ca. 90 my), as attested by the age of N-MORB (ca. $305 \mathrm{Ma}$ - this age is even older if the E-MORB dated at ca. 336 Ma are assumed to represent an ophiolite as suggested by Qian X. et al., 2015a) and the deposition of cherts from the early Permian to the Anisian within the Nan Uttaradit Suture Zone (Ueno and Hisada, 2001; Saesaengseerung et al., 2008). Secondly, this oceanic paleolithosphere should have been large enough to account for a subduction that lasted ca. 35 my. As this oceanic domain was probably quite large and comprised remnants that are now located only ca. $140 \mathrm{~km}$ to the Song Ma Suture Zone and its correlative Ailoashan Suture Zone (e.g., Roger et al., 2014), these oceanic domains were probably connected together (Fig. 14A).

The connection between these domains potentially lasted until the Early to the Middle Triassic, when the South China Block collided with the Indochina Block after a south-dipping subduction (e.g., Faure et al., 2014 and references therein) resulting in the closure of the Song Ma branch of the Paleotethys ocean. Similarly, the Ailaoshan branch of the Paleotethys closed during the Early Triassic after a south-dipping subduction (e.g., Lai C.-K. et al., 2014a, b; Liu H. et al., 2014), leaving only a residual oceanic domain now represented by the Nan Uttaradit - Luang Prabang Suture Zone (Fig. 14B).

From the early Triassic (and possibly from the late Permian, see below) to the late Triassic (Norian), the western margin of the Indochina Block experienced eastdipping subduction (Fig. 13B). The subduction polarity is inferred from the location of calk-alkaline, subduction related, magmatic rocks that crop out to the east of the Nan 
Uttaradit ophiolite and were emplaced from the late Permian to the Late Triassic (e.g., Kamvong et al., 2014; Zaw et al., 2014). This hypothesis is however not unanimously shared and a west-dipping slab is sometimes favored (e.g., Hirsh et al., 2006; Boonsoong et al., 2011). In the Luang Prabang Basin, the volcaniclastic sediments that constitute a substantial part of the PCS, the RCS, and the LPT fms. record the subduction related volcanism (Fig. 14B and C). From the Early Triassic and up to the beginning of the Norian (between ca. 250 and ca. $225 \mathrm{Ma}$ ) this volcanism is only documented as reworked elements (i.e., volcaniclasts, volcanic boulders). In the proposed model, an intra-arc position is tentatively ascribed to the Luang Prabang Basin, for instance, by comparison with the present day distribution of tholeiitic rocks that are intimately associated with calk-alkaline magmatic suites cropping out within the Japan arc (e.g., Ohba et al., 2009) or the Sunda-Banda arc (e.g., Wheller et al., 1987).

During the Norian, between ca. 225 and 215 Ma (Fig. 13C), the volcanism is directly documented by syn-sedimentary deposits in the RCS and the LTP fms. The emplacement age of the arc tholeiites that constitute part of the MRU remains unknown from the present geochronological evidence. Despite this uncertainty, we assume that the mafic and felsic magmatisms are roughly coeval, as observed in some present-day magmatic arcs (e.g., Wheller et al., 1987; Ohba et al., 2009). At the end of the Norian, the Luang Prabang Basin was drowned as attested by conodonts and ammonites from the ML Fm. (Blanchard et al., 2013). This implies a yet unknown connection with an oceanic domain, the most probable being a connection with the residual Nan Uttaradit branch of the Paleotethys ocean (Fig. 14 C).

After the Norian (Fig. 13D), the whole deposits of the Luang Prabang Basin experienced thrusting and folding, as evidenced by the Luang Prabang nappe (Bush et al., 1996) and the Luang Prabang syncline (Blanchard et al., 2013). These deformations 
are tentatively attributed to a post-Norian collision between the Indochina and the Simao blocks (Fig. 14 D). Even though speculative given the present day remote location of the Luang Prabang Basin with respect to the Malay Peninsula, and the potential large tectonic offset between these areas (e.g., Ridd, 2012), there are some striking similarities regarding their Late Triassic geodynamic evolution. Particularly, the timing and the dipping of the subduction in the Luang Prabang area compare well with the Late Triassic subduction described in Peninsular Malaya (e.g., Searle et al., 2012; Metcalfe, 2013).

In the Luang Prabang area, if a collision really occurred after the Norian, it should have induced some tectono-metamorphic events. Such evidences are however faint: Late Triassic or Jurassic regional metamorphism and/or collisional granite are not reported, up to now, in northern Laos. The only perceptible manifestation of a potential collisional, or at least of a tectonic event inducing significant deformation, is an unconformity spanning from the Late Triassic to the Late Jurassic documented in northern Thailand and Laos (Stokes et al., 1996; Lovatt Smith and Stokes, 1997; Racey, 2009). A nearly coeval unconformity, ending with the deposition of Middle Jurassic molasses, is also reported in Yunnan, south China (Zhang R.Y. et al., 1993). The significance of this unconformity has been a troublesome problem since its initial recognition by Stokes et al. (1996) in northern Thailand and Laos and has been tentatively attributed to a Late Jurassic orogeny, called the "Cimmerian event" (Stokes et al., 1996; Lovatt Smith and Stokes, 1997; Racey, 2009). In Yunnan, this unconformity has been attributed to the collision between the Simao and the Baoshan (i.e., part of the Sibumasu Block as depicted in Fig. 1A) blocks (Zhang R.Y. et al., 1993). The recognition of a long lasting, subduction related volcanism that spanned most of the Triassic (late Triassic included) in northern Laos re-emphasizes the significance of this unconformity. 


\section{Conclusion}

The east Tethyan domain is composed of several blocks that constitute a "paleogeographic jigsaw". This "jigsaw" recently attracted a large number of models to account for the tectonic evolution in the area. The Luang Prabang Basin, located in the core of this "jigsaw", is filled with volcanic and volcaniclastic series pointing toward an arc related volcanism. The long duration of this volcanic activity, assessed by U$\mathrm{Pb} /$ zircon dating on both volcanic and volcaniclastic rocks, confirms an active margin setting for this volcanism. Indeed, the inspection of the maximum depositional ages of the samples with respect to their known stratigraphic locations suggests that sedimentation and volcanic activity were coeval. Combined with the dating of reworked volcanic andesitic to dacitic boulders, as well as the dating of a large number of zircon grains enclosed within the volcaniclastic rocks, a continuous volcanic activity that lasted during ca. $35 \mathrm{my}$, between ca. 250 and $215 \mathrm{Ma}$, is evidenced in the vicinity of the Luang Prabang Basin.

Together with the recent recognition of a Nan Uttaradit Luang Prabang Suture, the occurrence of this magmatic arc active from the earliest Triassic up to the Late Triassic provides new insights for the paleogeography, the timing and the overall geodynamic evolution of the northern Indochina and Simao blocks. There is thus a growing body of evidence to locate the western boundary of the Indochina Block along the Nan Uttaradit Luang Prabang Suture. This plate boundary was the locus of an active magmatic arc during most of the Triassic, before it merged with the Simao micro-plate, for which the exact limits remain to be clarified. 
As the arc related volcanic activity lasted up to the Norian, a continental collision that classically follows an oceanic subduction happened after the Late Triassic. Evidence for such a collision are faint, the only potential manifestation being a major unconformity spanning from the Late Triassic to the Late Jurassic documented in northern Thailand, Laos and Yunnan. Complementary studies are needed to better characterize this unconformity, notably its spatial extent. Investigations in other basins filled up by volcaniclastic sediments that constitute a key target to document the volcanism, might help to unravel the complex, and still poorly understood, tectonic evolution of the east Tethyan domain.

\section{Acknowledgements}

The geochronological analyses were supported by the Observatoire des Sciences de l'Univers de Rennes (OSUR). Other analyses have been funded by the Centre National de la Recherche Scientifique (CNRS - "Soutien de base"). X. Le Coz and Y. Lepagnot (OSUR) are acknowledged for the thin sections and rock crushing preparation, respectively. Constructive reviews from I. Sevastjanova, A.J. Barber and from the Editor I. Metcalfe helped to improve the quality and clarity of this paper.

\section{References}

Andersen, T., 2005. Detrital zircons as tracers of sedimentary provenance: limiting conditions from statistics and numerical simulation. Chemical Geology 216, 249-270.

Armstrong-Altrin, J.S., Verma, S.P., 2005. Critical evaluation of six tectonic setting discrimination diagrams using geochemical data of Neogene sediments from known tectonic settings. Sedimentary Geology 177, 115-129. 
Baier, J., Audétat, A., Keppler, H., 2008. The origin of the negative niobium tantalum anomaly in subduction zone magmas. Earth and Planetary Science Letters 267, 290300.

Ballouard, C., Boulvais, P., Poujol, M., Gapais, D., Yamato, P., Tartèse, R., Cuney, M., 2015. Tectonic record, magmatic history and hydrothermal alteration in the Hercynian Guérande leucogranite, Armorican Massif, France. Lithos 220-223, 1-22.

Bao, N.X., Thuc, D.D., Dung, H.T., Bac, N.V., Lam, N.N., Ty, N.V., 2004. Geology and mineral resources of Van Yen sheet (F-48-XXVII), department of geology and minerals of Vietnam, Ha Noi.

Barr, S.M., Macdonald, A.S., 1987. Nan River suture zone, northern Thailand. Geology 15, 907-910.

Barr, S.M., Macdonald, A.S., Ounchanum, P., Hamilton, M.A., 2006. Age, tectonic setting and regional implications of the Chiang Khong volcanic suite, northern Thailand. Journal of the Geological Society of London 163, 1037-1046.

Battail, B., 2009. Late Permian dicynodont fauna from Laos. Geological Society, London, Special Publication 315, 33-40.

Bau, M., 1996. Controls on the fractionation of isovalent trace elements in magmatic and aqueous systems : evidence from $\mathrm{Y} / \mathrm{Ho}, \mathrm{Zr} / \mathrm{Hf}$, and lanthanide tetrad effect. Contribution to Mineralogy and Petrology 123, 323-333.

Bercovici, A., Bourquin, S., Broutin, J., Steyer, J.-S., Battail, B., Véran, M., Vacant, R., Khenthavong, B., Vongphamany, S., 2012. Permian continental paleoenvironments in Southeastern Asia: New insights from the Luang Prabang Basin (Laos). Journal of Asian Earth Sciences 60, 197-211.

Blanchard, S., Rossignol, C., Bourquin, S., Dabard, M.-P., Hallot, E., Nalpas, T., Poujol, M., Battail, B., Jalil, N.-E., Steyer, J.-S., Vacant, R., Véran, M., Bercovici, A., Diez, J.B., 
Paquette, J.-L., Khenthavong, B., Vongphamany, S., 2013. Late Triassic volcanic activity in South-East Asia: new stratigraphical, geochronological and paleontological evidence from the Luang Prabang Basin (Laos). Journal of Asian Earth Sciences 70-71, 8-26.

Bohrson, W.A., Reid, M.R., 1997. Genesis of Silicic Peralkaline Volcanic Rocks in an Ocean Island Setting by Crustal Melting and Open-system Processes: Socorro Island, Mexico. Journal of Petrology 38, 1137-1166.

Boonsoong, A., Panjasawatwong, Y., Metparsopsan, K., 2011. Petrochemistry and tectonic setting of mafic volcanic rocks in the Chon Daen-Wang Pong area, Phetchabun, Thailand. Isl. Arc 20, 107-124.

Braun, J.-J., Pagel, M., Muller, J.-P., Bilong, P., Michard, A., Guillet, B., 1990. Cerium anomalies in lateritic profiles. Geochimica and Cosmochimica Acta 54, 781-795.

Briqueu, L., Bougault, H., Joron, J.L., 1984. Quantification of Nb, Ta, Ti and V anomalies in magmas associated with subduction zones: petrogenetic implications. Earth and Planetary Science Letters 68, 297-308.

Bureau of Geology and Mineral Resources of Yunnan Province, 1990. Geological map of Yunnan Province. Geological Publishing House, Beijing.

Burrett, C.F., 1974. Plate tectonics and the fusion of Asia. Earth and Planetary Science Letters. 21, 181-189.

Burrett, C.F., Meffre, S., Lai, C.K., Khositanont, S., Chaodumrong, P., Udchachon, M., Ekins, S., Halpin, J.A., 2014. The configuration of Greater Gondwana-Evidence from LA ICPMS, U-Pb geochronology of detrital zircons from the Palaeozoic and Mesozoic of Southeast Asia and China. Gondwana Research 26, 31-51. 
Bush, V.A., Gatinskii, Y.G., Elizar, Y.Z., Ivanov, G.M., Kozlov, V.V., Lartsev, V.S., Sulidikondrat'ev, E.D., 1996. New Data on the Tectonics of the Indosinian Massif and the Surrounding Zones. Geotectonics 30, 71-83.

Cabanis, B., Lecolle, M., 1989. Le Diagramme La/10-Y/15-Nb/8: un outil pour la discrimination des séries volcaniques et la mise en évidence des processus de mélange et/ou de contamination crustale. Comptes Rendus de l'Académine des Sciences Serie II 309, 2023-2029.

Cai, J.-X., Zhang, K.-J., 2009. A new model for the Indochina and South China collision during the Late Permian to the Middle Triassic. Tectonophysics 467, 35-43.

Carter, A., Clift, P.D., 2008. Was the Indosinian orogeny a Triassic mountain building or a thermotectonic reactivation event? Comptes Rendus Geosciences 340, 83-93.

Carignan, J., Hild, P., Mevelle, G., Morel, J., Yeghicheyan, D., 2001. Routine Analyses of Trace Elements in Geological Samples using Flow Injection and Low Pressure On-Line Liquid Chromatography Coupled to ICP-MS: A Study of Geochemical Reference Material BR, DR-N, UB-N, AN-G and GH. Geostandard Newsletter 25, 187-198.

Cocks, L.R.M., Torsvik, T.H., 2013. The dynamic evolution of the Palaeozoic geography of eastern Asia. Earth-Science Review 117, 40-79.

Cohen, K.M., Finney, S.C., Gibbard, P.L., Fan, J.-X., 2013 (updated, v2015/01). The ICS International Chronostratigraphic Chart. Episodes 36, 199-204.

Colgan, J.P., Dumitru, T.A., McWilliams, M., Miller, E.L., 2006. Timing of Cenozoic volcanism and Basin and Range extension in northwestern Nevada: New constraints from the northern Pine Forest Range. Geological Society of America Bulletin 118, 126-139. 
Cotten, J., Dez, A. Le, Bau, M., Caroff, M., 1995. Origin of anomalous rare-earth element and yttrium enrichments in subaerially exposed basalts: evidence from French Polynesia. Chemical Geology 2541, 115-138.

Counillon, M., 1896. Documents pour servir à l'étude géologique des environs de Luang Prabang (Cochinchine). Comptes Rendus Hebdomadaires de l'Académie des Sciences, Paris 123, 1330-1333.

Dickinson, W.R., Gehrels, G.E., 2009. Use of U-Pb ages of detrital zircons to infer maximum depositional ages of strata: A test against a Colorado Plateau Mesozoic database. Earth and Planetary Science Letters 288, 115-125.

Drake, M.J., Weill, D.F., 1975. Partition of Sr, Ba, Ca, Y, $\mathrm{Eu}^{2+}, \mathrm{EU}^{3+}$, and other REE between plagioclase feldspar and magmatic liquid - An experimental study. Geochimica and Cosmochimica Acta 39, 689-712. doi:10.1016/0016-7037(75)90011-3

Faure, M., Lepvrier, C., Nguyen, V.V., Vu, T.V., Lin, W., Chen, Z., 2014. The South China block-Indochina collision: where, when, and how? Journal of Asian Earth Sciences 79, $260-274$.

Feng, Q., Chonglakmani, C., Helmcke, D., Ingavat-Helmcke, R., Liu, B., 2005. Correlation of Triassic stratigraphy between the Simao and Lampang-Phrae Basins: implications for the tectonopaleogeography of Southeast Asia. Journal of Asian Earth Sciences 24, $777-785$.

Ferrari, O.M., Hochard, C., Stampfli, G.M., 2008. An alternative plate tectonic model for the Palaeozoic-Early Mesozoic Palaeotethyan evolution of Southeast Asia (Northern Thailand-Burma). Tectonophysics 451, 346-365.

Ford, M.T., Grunder, A.L., Duncan, R.A., 2013. Bimodal volcanism of the High Lava Plains and Northwestern Basin and Range of Oregon: Distribution and tectonic implications of age-progressive rhyolites. Geochemistry, Geophysics, Geosystems 14, 2836-2857. 
Geological map of Lao People’s Democratic Republic, 1: 1500 000, 1990. United Nation publication.

Geological map of Thailand, 1: 2000 000, Ridd, M.F., Barber, A.J., Crow, M.J., 2011. In: Ridd, M.F., Barber, A.J., Crow, M.J. (Eds.), The Geology of Thailand. The Geological Society, London, pp. 19-31.

Halpin, J.A., Tran, H.T., Lai, C.-K., Meffre, S., Crawford, A.J., Zaw, K., 2015. U-Pb zircon geochronology and geochemistry from NE Vietnam: A "tectonically disputed" territory between the Indochina and South China blocks. Gondwana Research doi:10.1016/j.gr.2015.04.005

Hawkesworth, C.J., Turner, S., Gallagher, K., Hunter, A., Bardshaw, T., Rogers, N., 1995. Calc-alkaline magmatism, lithospheric thinning and extension in the Basin and Range. Journal of Geophysical Research 100, 10,271-10,286.

Helmcke, D., 1985. The Permo-Triassic "Paleotethys" in mainland Southeast-Asia and adjacent parts of China. Geolische Rundschau 74, 215-228.

Hennig, D., Lehmann, B., Frei, D., Belyatsky, B., Zhao, X.F., Cabral, A.R., Zeng, P.S., Zhou, M.F., Schmidt, K., 2009. Early Permian seafloor to continental arc magmatism in the eastern Paleo-Tethys: $\mathrm{U}-\mathrm{Pb}$ age and $\mathrm{Nd}-\mathrm{Sr}$ isotope data from the southern Lancangjiang zone, Yunnan, China. Lithos 113, 408-422.

Heppe, K., Helmcke, D., Wemmer, K., 2007. The Lancang River Zone of southwestern Yunnan, China: A questionable location for the active continental margin of Paleotethys. Journal of Asian Earth Sciences 30, 706-720.

Hirsch, F., Ishida, K., Kozai, T., Meesook, A., 2006. The welding of Shan-Thai. Geosciences Journal 10, 195-204.

Hutchison, C.S., 1975. Ophiolite in Southeast Asia. Geol. Soc. Am. Bull. 86, 797-806. 
Jackson, S.E., Pearson, N.J., Griffin, W.L., Belousova, E.A., 2004. The application of laser ablation-inductively coupled plasma-mass spectrometry to in situ $\mathrm{U}-\mathrm{Pb}$ zircon geochronology. Chemical Geology 211, 47-69.

Jian, P., Liu, D., Kröner, A., Zhang, Q., Wang, Y., Sun, X., Zhang, W., 2009a. Devonian to Permian plate tectonic cycle of the Paleo-Tethys Orogen in southwest China (I): Geochemistry of ophiolites, arc/back-arc assemblages and within-plate igneous rocks. Lithos 113, 748-766.

Jian, P., Liu, D., Kröner, A., Zhang, Q., Wang, Y., Sun, X., Zhang, W., 2009b. Devonian to Permian plate tectonic cycle of the Paleo-Tethys Orogen in southwest China (II): Insights from zircon ages of ophiolites, arc/back-arc assemblages and within-plate igneous rocks and generation of the Emeishan CFB province. Lithos 113, 767-784.

Kamvong, T., Meffre, S., Maas, R., Stein, H., Lai, C.-K., 2014. Adakites in the Truong Son and Loei fold belts, Thailand and Laos: Genesis and implications for geodynamics and metallogeny. Gondwana Research 26, 165-184.

Lai, C.-K., Meffre, S., Crawford, A.J., Zaw, K., Halpin, J.A., Xue, C.-D., Salam, A., 2014a. The Central Ailaoshan ophiolite and modern analogs. Gondwana Research 26, 75-88.

Lai, C.-K., Meffre, S., Crawford, A.J., Zaw, K., Xue, C.-D., Halpin, J.A., 2014b. The Western Ailaoshan Volcanic Belts and their SE Asia connection: A new tectonic model for the Eastern Indochina Block. Gondwana Research 26, 52-74.

Le Maitre, R. W., Streckeisen, A., Zanettin, B., Le Bas, M. J., Bonin, B., Bateman, P., Bellieni, G., Dudek, A., Efremova, S., Keller, J., Lameyre, J., Sabine, P. A., Schmid, R., Sørensen, H., Woolley, A. R., 2002. Igneous rocks: A classification and glossary of terms. Le Maitre, R. W., Ed. (2nd ed., p. 236). Cambridge University Press, United Kingdom. 
Lepvrier, C., Maluski, H., Tich, V.V., Leyreloup, A., Thi, P.T., Vuong, N.V., 2004. The Early Triassic Indosinian orogeny in Vietnam (Truong Son Belt and Kontum Massif); implications for the geodynamic evolution of Indochina. Tectonophysics 393, 87-118.

Lepvrier, C., Vuong, N.V., Maluski, H., Thi, P.T., Vu, T.V., 2008. Indosinian tectonics in Vietnam. Comptes Rendus Geosciences 340, 94-111.

Le Roex, A.P., Bell, D.R., Davis, P., 2003. Petrogenesis of Group I Kimberlites from Kimberley, South Africa: Evidence from Bulk-rock Geochemistry. Journal of Petrology 44, 2261-2286. doi:10.1093/petrology/egg077

Li, G., Li, C., Ripley, E.M., Kamo, S., Su, S., 2012. Geochronology, petrology and geochemistry of the Nanlinshan and Banpo mafic-ultramafic intrusions: implications for subduction initiation in the eastern Paleo-Tethys. Contribution to Mineralogy and Petrology 164, 773-788.

Liu, H., Wang, Y., Cawood, P.A., Fan, W., Cai, Y., Xing, X., 2014. Record of Tethyan ocean closure and Indosinian collision along the Ailaoshan suture zone (SW China). Gondwana Research.

Liu, J., Tran, M.-D., Tang, Y., Nguyen, Q.-L., Tran, T.-H., Wu, W., Chen, J., Zhang, Z., Zhao, Z., 2012. Permo-Triassic granitoids in the northern part of the Truong Son belt, NW Vietnam: Geochronology, geochemistry and tectonic implications. Gondwana Research. 22, 628-644.

Lovatt Smith, P.F., Stokes, R.B., 1997. Geology and petroleum potential of the Khorat plateau basin in the Vientiane area of Lao P.D.R. Journal of Petroleum Geology 20, 2750.

Ludwig, K.R., 1998. On the Treatment of Concordant Uranium-Lead Ages. Geochimica and Cosmochimica Acta 62, 665-676. 
Ludwig, K.R., Mundil, R., 2002. Extracting reliable U-Pb ages and errors from complex populations of zircons from Phanerozoic tuffs, in: Goldschmidt Conference Abstract. p. A463.

Ludwig, K.R., 2012. User's Manual for a geochronological toolkit for Microsoft Excel. Berkeley Geochronological Center 75.

Malavieille, J., 1993. Late orogenic extension in mountain belts: insights from the Basin and Range and the Late Paleozoic Variscan belt. Tectonics 12, 1115-1130.

Malusà, M.G., Carter, A., Limoncelli, M., Villa, I.M., Garzanti, E., 2013. Bias in detrital zircon geochronology and thermochronometry. Chemical Geology 359, 90-107. doi:10.1016/j.chemgeo.2013.09.016

Marsh, J.S., 1991. REE fractionation and Ce anomalies in weathered Karoo dolerite. Chemical Geology 90, 189-194.

Meschede, M., 1986. A method of discriminating between different types of mid-ocean ridge basalts and continental tholeiites with the Nb-Zr-Y diagram. Chemical Geology $56,207-218$.

Metcalfe, I., 1988, Origin and assembly of south-east Asian continental terranes, in Audley-Charles, M.G. and Hallam, A. eds., Gondwana and Tethys, The Geological Society, London, Special Publication 37, p. 101-118.

Metcalfe, I., 2002. Permian tectonic framework and palaeogeography of SE Asia. Journal of Asian Earth Sciences. 20, 551-566.

Metcalfe, I., 2011. Tectonic framework and Phanerozoic evolution of Sundaland. Gondwana Research 19, 3-21.

Metcalfe, I., 2013. Tectonic evolution of the Malay Peninsula. Journal of Asian Earth Sciences 76, 195-213. doi:10.1016/j.jseaes.2012.12.011 
Middlemost, E.A.K., 1989. Iron oxidation ratios, norms and the classification of volcanic rocks. Chemical Geology 77, 19-26.

Mitchell, A.H.G., 1981. Phanerozoic plate boundaries in mainland SE Asia, the Himalayas and Tibet. Journal of the Geological Society, London. 138, 109-122. doi:10.1144/gsjgs.138.2.0109

Mitchell, A., Chung, S.-L., Oo, T., Lin, T.-H., Hung, C.-H., 2012. Zircon U-Pb ages in Myanmar: Magmatic-metamorphic events and the closure of a neo-Tethys ocean? Journal of Asian Earth Sciences 56, 1-23.

Morley, C.K., Charusiri, P., Watkinson, I.M., 2011. Structural geology of Thailand during the Cenozoic, in: Ridd, M.F., Barber, A.J., Crow, M.J. (Eds.), The Geology of Thailand. The Geological Society, London, pp. 19-31.

Morris, G.A., Larson, P.B., Hooper, P.R., 2000. “Subduction Style” Magmatism in a Nonsubduction Setting: the Colville Igneous Complex, NE Washington State, USA. Journal of Petrology 41, 43-67.

My, B.P., Hoanh, N.V., Ky, P.V., Tuyet, T.D., 2004. Geology and Mineral Resources of Kim Binh - Lao Cai sheet (F-48-VIII and F-48-XIV), Department of Geology and Minerals of Vietnam, Ha Noi.

Nakano, N., Osanai, Y., Sajeev, K., Hayasaka, Y., Miyamoto, T., Minh, N.T., Owada, M., Windley, B., 2010. Triassic eclogite from northern Vietnam: inferences and geological significance. Journal of Metamorphic Geology 28, 59-76.

Nemchin, A.A., Cawood, P.A., 2005. Discordance of the U-Pb system in detrital zircons: Implication for provenance studies of sedimentary rocks. Sedimentary Geology 182, 143-162. 
Ndjigui, P.-D., Bilong, P., Bitom, D., 2009. Negative cerium anomalies in the saprolite zone of serpentinite lateritic profiles in the Lomié ultramafic complex, South-East Cameroon. Journal of African Earth Sciences 53, 59-69.

Ohba, T., Matsuoka, K., Kimura, Y., Ishikawa, H., Fujimaki, H., 2009. Deep Crystallization Differentiation of Arc Tholeiite Basalt Magmas from Northern Honshu Arc, Japan. Journal of Petrology 50, 1025-1046.

Orberger, B., Lorand, J.P., Girardeau, J., Mercier, J.C.C., Pitragool, S., 1995. Petrogenesis of ultramafic rocks and associated chromitites in the Nan Uttaradit ophiolite, Northern Thailand. Lithos 35, 153-182.

Pearce, J.A., Cann, J.R., 1973. Tectonic setting of basic volcanic rocks determined using trace element analyses. Earth and Planetary Science Letters 19, 290-300.

Pearce, J.A., Gale, G.H., 1977. Identification of ore-deposition environment from traceelement geochemistry of associated igneous host rocks. Geological Society of London, Special Publication 7, 14-24.

Pearce, J.A., Norry, M.J., 1979. Petrogenetic implications of Ti, Zr, Y, and Nb variations in volcanic rocks. Contribution to Mineralogy and Petrology 69, 33-47.

Pearce, J.A., Harris, N.B.W., Tindle, A.G., 1984. Trace Element Discrimination Diagrams for the Tectonic Interpretation of Granitic Rocks. Journal of Petrology 25, 956-983.

Peng, T., Wilde, S.A., Wang, Y., Fan, W., Peng, B., 2013. Mid-Triassic felsic igneous rocks from the southern Lancangjiang Zone, SW China: Petrogenesis and implications for the evolution of Paleo-Tethys. Lithos 168-169, 15-32.

Poujol, M., Anhaeusser, C.R., 2001. The Johannesburg Dome, South Africa: new single zircon $\mathrm{U}-\mathrm{Pb}$ isotopic evidence for early Archean granite-greenstone development within the central Kaapvaal Craton. Precambrian Research 108, 139-157. 
Pullen, A., Kapp, P., Gehrels, G.E., Vervoort, J.D., Ding, L., 2008. Triassic continental subduction in central Tibet and Mediterranean-style closure of the Paleo-Tethys Ocean. Geology 36, 351-354.

Qian, X., Feng, Q.-L., Yang, W., Wang, Y., Chonglakmani, C., Monjai, D., 2015a. Geochronological and geochemical constraints on the mafic rocks along the Luang Prabang zone: Carboniferous back-arc setting in northwest Laos. Lithos, in press. doi: 10.1016/j.lithos.2015.07.019

Qian, X., Feng, Q.-L., Yang, W., Wang, Y., Chonglakmani, C., Monjai, D., 2015b. Arc-like volcanic rocks in NW Laos : Geochronological and geochemical constraints and their tectonic implications. Journal of Asian Earth Sciences 98, 342-357.

Racey, A., 2009. Mesozoic red bed sequences from SE Asia and the significance of the Khorat Group of NE Thailand. Geological Society of London, Special Publication 315, $41-67$.

Ridd, M.F., 1971. South-East Asia as a part of Gondwanaland. Nature 234, 531-533.

Ridd, M.F., 2012. The role of strike-slip faults in the displacement of the Palaeotethys suture zone in Southeast Thailand. Journal of Asian Earth Sciences 51, 63-84.

Ridd, M.F., 2014. East flank of the Sibumasu block in NW Thailand and Myanmar and its possible northward continuation into Yunnan: a review and suggested tectonostratigraphic interpretation. Journal of Asian Earth Sciences 1-15.

Roger, F., Jolivet, M., Maluski, H., Respaut, J.-P., Münch, P., Paquette, J.-L., Tich, V.V., Vuong, N.V., 2014. Emplacement and cooling of the Dien Bien Phu granitic complex: Implications for the tectonic evolution of the Dien Bien Phu Fault (Truong Son Belt, NW Vietnam). Gondwana Research 26, 785-801.

Roser, B.P., Korsch, R.J., 1986. Determination of tectonic setting of sandstone-mudstone suites using $\mathrm{SiO}_{2}$ content and $\mathrm{K}_{2} \mathrm{O} / \mathrm{Na}_{2} \mathrm{O}$ ratio. The Journal of Geology 94, 635-650. 
Rubatto, D., 2002. Zircon trace element geochemistry: partitioning with garnet and the link between $\mathrm{U}-\mathrm{Pb}$ ages and metamorphism. Chemical Geology 184, 123-138. doi:10.1016/S0009-2541(01)00355-2

Ryan, K.M., Williams, D.M., 2007. Testing the reliability of discrimination diagrams for determining the tectonic depositional environment of ancient sedimentary basins. Chemical Geology 242, 103-125.

Saesaengseerung, D., Sashida, K., Sardsud, A., 2008. Discovery of Middle Triassic radiolarian fauna from the Nan area along the Nan-Uttaradit suture zone, northern Thailand. Paleontological Research. 12, 397-409.

Salam, A., Zaw, K., Meffre, S., McPhie, J., Lai, C.-K., 2014. Geochemistry and geochronology of the Chatree epithermal gold-silver deposit: Implications for the tectonic setting of the Loei Fold Belt, central Thailand. Gondwana Research 26, 198-217.

Schmid, R., 1981. Descriptive nomenclature and classification of pyroclastic deposits and fragments: Recommendations of the IUGS Subcommission on the Systematics of Igneous Rocks. Geology 9, 41-43.

Searle, M.P., Whitehouse, M.J., Robb, J., Ghani, A.A., Hutchison, C.S., Sone, M., Ng, W.-P., Roselee, M.H., Chung, S.-L., Oliver, G.J.H., 2012. Tectonic evolution of the SibumasuIndochina terrane collision zone in Thailand and Malaysia: constraints from new U$\mathrm{Pb}$ zircon chronology of SE Asian tin granitoids. Journal of the Geological Society, London 169, 489-500. doi:10.1144/0016-76492011-107.Tectonic

Sengör, A.M., 1979. Mid-Mesozoic closure of Permo-Triassic Tethys and its implications. Nature 279, 590-593.

Sláma, J., Košler, J., 2012. Effects of sampling and mineral separation on accuracy of detrital zircon studies. Geochemistry, Geophysics, Geosystems 13, Q05007. doi:10.1029/2012GC004106 
Son, P., Thuc, D.D., Thang, N.D., Ty, T.V., 2005. Geology and Mineral Resources of Muong Kha - Son La sheet (F-48-XXV and F-48-XXVI), Department of Geology and Minerals of Vietnam, Ha Noi.

Sone, M., Metcalfe, I., 2008. Parallel Tethyan sutures in mainland Southeast Asia: New insights for Palaeo-Tethys closure and implications for the Indosinian orogeny. Comptes Rendus Geosciences 340, 166-179.

Srichan, W., Crawford, A.J., Berry, R.F., 2009. Geochemistry and geochronology of Late Triassic volcanic rocks in the Chiang Khong region, northern Thailand. Island Arc 18, $32-51$.

Steyer, J.-S., 2009. The geological and palaeontological exploration of Laos; following in the footsteps of J. B. H. Counillon and A. Pavie, Geological Society of London, Special Publication 315, 25-32.

Stokes, R.B., Lovatt Smith, P.F., Soumphonphakdy, K., 1996. Timing of the Shan-ThaiIndochina collision: new evidence from the Pak Lay Foldbelt of the Lao PDR, Geological Society of London, Special Publication 106, p. 225-232.

Sun, S.-S., McDonough, W.F., 1989. Chemical and isotopic systematics of oceanic basalts: implications for mantle composition and processes. Geological Society of London, Special Publication 42, 313-345.

Trung, N.M., Tsujimori, T., Itaya, T., 2006. Honvang serpentinite body of the Song Ma fault zone, Northern Vietnam: A remnant of oceanic lithosphere within the Indochina-South China suture. Gondwana Research 9, 225-230.

Tuyet, T.D., Thuy, D.V., Lu, N.D., Than, N.H., Duong, P.V., Hung, T.T., 2005a. Geology and mineral resources of Khi Su - Muong Te sheet (F-48-VII and F-48-XIII), department of geology and minerals of Vietnam, Ha Noi 
Tuyet, T.D., Thong, A.V., Hung, N.B., Hoi, N.V., Duong, P.V., 2005b. Geology and mineral resources of Phong Sa Ly - Dien Bien Phu sheet (F-48-XIX and F-48-XX), department of geology and minerals of Vietnam, Ha Noi

Ueno, K., Hisada, K., 2001. The Nan-Uttaradit-Sa Kaeo Suture as a Main Paleo-Tethyan Suture in Thailand: Is it Real? Gondwana Research. 4, 804-806.

Verma, S.P., Armstrong-Altrin, J.S., 2013. New multi-dimensional diagrams for tectonic discrimination of siliciclastic sediments and their application to Precambrian basins. Chemical Geology 355, 117-133.

Verma, S.P., Verma, S.K., 2013. First 15 probability-based multidimensional tectonic discrimination diagrams for intermediate magmas and their robustness against postemplacement compositional changes and petrogenetic processes. Turkish Journal of Earth Sciences 22, 931-995.

Verma, S.P., Pandarinath, K., Verma, S.K., Agrawal, S., 2013. Fifteen new discriminantfunction-based multi-dimensional robust diagrams for acid rocks and their application to Precambrian rocks. Lithos 168-169, 113-123.

Vermeesch, P., 2012. On the visualisation of detrital age distributions. Chemical Geology 312-313,190-194. doi:10.1016/j.chemgeo.2012.04.021

Vượng, N.V., Hansen, B.T., Wemmer, K., Lepvrier, C., Tích, V.V., Thắng, T.T., 2013. U/Pb and Sm/Nd dating on ophiolitic rocks of the Song Ma suture zone (northern Vietnam):

Evidence for upper Paleozoic paleotethyan lithospheric remnants. Journal of Geodynamics 69, 140-147.

Wakita, K., Metcalfe, I., 2005. Ocean Plate Stratigraphy in East and Southeast Asia. Journal of Asian Earth Sciences 24, 679-702.

Wang, B., Wang, L., Chen, J., Yin, F., Wang, D., Zhang, W., Chen, L., Liu, H., 2014. Triassic three-stage collision in the Paleo-Tethys: Constraints from magmatism in the 
Jiangda-Deqen-Weixi continental margin arc, SW China. Gondwana Research 26, $475-491$.

Wang, Q., Deng, J., Li, C., Li, G., Yu, L., Qiao, L., 2014. The boundary between the Simao and Yangtze blocks and their locations in Gondwana and Rodinia: Constraints from detrital and inherited zircons. Gondwana Research 26, 438-448.

Wang, Y., Zhang, A., Fan, W., Peng, T., Zhang, F., Zhang, Y., Bi, X., 2010. Petrogenesis of late Triassic post-collisional basaltic rocks of the Lancangjiang tectonic zone, southwest China, and tectonic implications for the evolution of the eastern Paleotethys: Geochronological and geochemical constraints. Lithos 120,529-546.

Wheller, G.E., Varne, R., Foden, J.D., Abbott, M.J., 1987. Geochemistry of Quaternary volcanism in the Sunda-Banda arc, Indonesia, and three-component genesis of islandarc basaltic magmas. Journal of Volcanology and Geothermal Research 32, 137-160.

Wiedenbeck M., Alle P., Corfu F, Griffin W.L., Meier M., Oberli F., von Quadt A., Roddick J.C. and Spiegel W.,1995. Three natural zircon standards for U-Th-Pb, Lu-Hf, trace element and REE analyses. Geostandard Newsletter 19, 1-23.

Winchester, J.A., Floyd, P.A., 1977. Geochemical discrimination of different magma series and their differenciation products using immobile elements. Chem. Geol. 20, 325-343.

Wood, D.A., 1980. diagram to problems of tectonomagmatic classification and to establishing the nature of crustal contamination of basaltic lavas of the British Tertiary Volcanic Province. Earth and Planetary Science Letters 50, 11-30.

Wu, H., Boulter, C.A., Ke, B., Stow, D.A.V., Wang, Z., 1995. The Changning-Menglian suture zone; a segment of the major Cathaysian-Gondwana divide in Southeast Asia. Tectonophysics 242, 267-280. 
Wu, H., Boulter, C.A., Ke, B., Stow, D.A.V., Wang, Z., 1998. The Changning-Menglian suture zone; a segment of the major Cathaysian-Gondwana divide in Southeast Asia Reply. Tectonophysics 290, 322-323.

Yang, W., Qian, X., Feng, Q., Shen, S., Chonglakmani, C., accepted. Zircon U-Pb geochronological evidence for the evolution of the Nan-Uttaradit Suture in northern Thailand. Journal of Earth Sciences 1-11.

Zaw, K., Meffre, S., Lai, C.-K., Burrett, C.F., Santosh, M., Graham, I., Manaka, T., Salam, A., Kamvong, T., Cromie, P., 2014. Tectonics and metallogeny of mainland Southeast Asia - A review and contribution. Gondwana Research 26, 5-30.

Zhang, K.-J., 1998. The Changning-Menglian suture zone: a segment of the major Cathaysian-Gondwana divide in Southeast Asia - Comment. Tectonophysics 290, $319-321$.

Zhang, R.Y., Cong, B.L., Maruyama, S., Liou, J.G., 1993. Metamorphism and Tectonic Evolution of the Lancang Paired Metamorphic Belts, South-Western China. Journal of Metamorphic Geology 11, 605-619.

Zhang, R.Y., Lo, C.-H., Chung, S.-L., Grove, M., Omori, S., Iizuka, Y., Liou, J.G., Tri, T.V., 2013. Origin and Tectonic Implication of Ophiolite and Eclogite in the Song Ma Suture Zone between the South China and Indochina Blocks. Journal of Metamorphic Geology 31, $49-62$.

Zhang, R.Y., Lo, C.-H., Li, X.-H., Chung, S.-L., Anh, T.T., Tri, T.V., 2014. U-Pb dating and tectonic implication of ophiolite and metabasite from the Song Ma Suture Zone, northern Vietnam. American Journal of Science 314, 649-678. 


\section{Figures and tables caption}

\section{Figures}

Figure 1. Tectonic subdivisions and simplified map of the Triassic and Jurassic deposits in South East Asia.

A. Tectonic subdivisions of South East Asia, after Metcalfe, 2011. Other tectonic subdivisions have been proposed, see Ferrari et al., 2008; Barr et al., 2006; Ridd, 2014; Burrett et al., 2014; Zaw et al., 2014. Bold box refers to the area enlarged in Fig. 1B.

B. Simplified regional tectonic map and distribution of Triassic and Jurassic sedimentary and magmatic rocks. Compilation after various sources; geological background after the geological map of Laos (1: 1500 000; United Nations publication, 1990), the geological map of the Yunnan Province (1: 500 000; Bureau of Geology and Mineral Resources of Yunnan Province, 1990), the geological map of Thailand (1: 2000 000, Ridd et al., 2011; Morley et al., 2011), and 5 geological maps of north Vietnam at the 1: 200000 scale: Tuyet et al., 2005a (Khi Su - Muong Te); My et al., 2004 (Kim Binh - Lao Cai); Son et al., 2005 (Muong Kha - Son La); Tuyet et al., 2005b (Phong Sa Ly - Dien Bien Phu); Bao et al., 2004 (Van Yen).

Major Cenozoic faults: MYF: Mae Yuam Fault, MPF: Mae Ping Fault, MF: Menxing Fault, NUF: Nan Uttaradit Fault, LF: Lincang Fault, DBPF: Dien Bien Phu Fault, RRF: Red River Fault, SF: Sagaing Fault. Suture zones (definite or supposed): CM: Changning Menglian, JH: Jinghong, LP: Luang Prabang; SK: Sra Kaeo, NU: Nan Uttaradit, PK: Poko, TK: Tamky Metamorphic ages: a: $230.5 \pm 8.2 \mathrm{Ma}$, U-Pb/zircon, Zhang R.Y. et al., 2013; b: $243 \pm 4$ Ma, Th-U-Pb/monazite, Nakano et al., 2010; c: $294 \pm 1$ Ma, Ar-Ar/phengite, Heppe et al., 2007; d: $269 \pm 12$ Ma, K-Ar/actinolite; Barr and MacDonald (1987). 
Circled numbers refer to various hypotheses proposed about the spatial continuity of suture zones in order to correlate the ophiolitic segments together. See text for explanation.

Figure 2. Geological map of the Luang Prabang Basin.

A. Geological map of the Luang Prabang Basin (after Blanchard et al., 2013) and location of the samples selected for whole rock geochemical analyses and $\mathrm{U}-\mathrm{Pb}$ dating on zircon along with samples already dated by Blanchard et al. (2013).

B. Cross section (after Blanchard et al., 2013).

C. Simplified chronostratigraphic chart of the Luang Prang Basin. Samples are organized following their stratigraphic position. Stratigraphic chart is the International Chronostratigraphic Chart v2015/01 (Cohen et al., 2013, updated). Wuchia.: Wuchiapingian, Ch.: Changsingian, In.: Induan, Ole.: Olenekian, Rha.: Rhaetian.

Figure 3. Outcrop and thin section photographs of the representative samples.

A. Basaltic pillow-lava with hyaloclastic material embedded between pillow-lavas.

B. Basalt from the Mafic Rock Unit (sample LP 22), plane-polarized light. 1: weathered clinopyroxene phenocrysts with typical sector twinning. 2: Secondary quartz and chlorite disseminated within a microlitic groundmass.

C. Basalt from the Mafic Rock Unit (sample LP 24), cross-polarized light. 1: euhedral plagioclase phenocrysts. 2: pyroxene phenocyst, embedded in a groundmass rich in plagioclase microlites. 
D. Basalt from the Mafic Rock Unit (sample LP 25), plane-polarized light. 1: weathered feldspar phenocryst. 2: quartz vein. 3: weathered plagioclase microlites and chlorite extensively disseminated within the groundmass. 4: sub-euhedral opaque mineral.

E. Coarse to very coarse-grained tuffaceous arenite from the Mafic Rock Unit (sample LP 34), plane-polarized light. 1: sub-rounded, weathered volcaniclast with a porphyritic microlithic texture. 2: monocrystalline, angular slightly weathered and slightly greenish clinopyroxene (aegyrine augite?).

F. Well sorted, small-grained tuffaceous arenite from the Mafic Rock Unit (sample LP 40), plane-polarized light. 1: sub-rounded, well sorted plagioclase, pyroxene and quartz (mainly monocrystalline). 2. Sparitic calcite.

G. Dacitic boulder from the Red Claystone Formation (sample LP 68), cross-polarized light. 1: pseudomorph after a Fe, Mg rich mineral (possibly hornblende). 2: plagioclase phenocryst within a groundmass rich in plagioclase microlites.

H. Dactic boulder from the Luang Prabang Tuffite Formation (sample LP 70), planepolarized light. 1: corroded quartz phenocryst. 2: pseudomorphs from former hydroxylbearing mafic phenocrysts, such as amphibole (hornblende?) and/or biotite. 3: chlorite disseminated within the groundmass. 4: strongly seritized plagioclase phenocryst. 5: titanite.

Figure 4. Chemical classification of volcanic rocks from the Luang Prabang Basin.

A. Total alkali versus silica diagram (TAS, Le Maitre et al., 2002) with $\mathrm{SiO}_{2}, \mathrm{Na}_{2} \mathrm{O}$ and $\mathrm{K}_{2} \mathrm{O}$ recalculated to $100 \%$ on a volatile free basis. Note that the LOI is higher than $2.5 \%$ for all of these samples except LP 25; for that reason this classification is considered as provisional. 
B. $\mathrm{Zr} / \mathrm{TiO}_{2}$ versus $\mathrm{Nb} / \mathrm{Y}$ diagram (Winchester and Floyd, 1977), with Ti recalculated to $100 \%$ on a volatile free basis.

Figure 5. Normalized Rare Earth Elements and multi-elements diagrams for the volcanic and volcaniclastic rocks of the Luang Prabang Basin.

A. Chondrite normalized Rare Earth Elements and Y (inserted between Dy and Ho) spectra. Normalizing values: C1 chondrite, Sun S.-S. and McDonough (1989).

B. Primitive mantle normalized multi-elements spectra.

Normalizing values: primitive mantle, Sun S.-S. and McDonough (1989). Major elements concentrations are recalculated to $100 \%$ on a volatile free basis.

Figure 6. Tectonic discrimination diagrams for the basaltic rocks of the MRU (after Verma and Verma, 2013).

DF: Discriminant Functions. CA: Continental Arc; IA: Island Arc; Col: Collision; CR+OI: Continental Rift + Oceanic Island tectonic settings. Pie chart represents the calculated probabilities for the set of samples to belong to each field taken into account in the five discrimination diagrams. Shaded diagram: a posteriori determined inoperative diagram (island arc field absent in this diagram).

Figure 7. Bivariate diagrams with immobile elements plotted as the variables.

The arrows underline the mixing trends from the volcanic rocks to the epiclastic poles of unknown compositions. 
Figure 8. Tectonic discrimination diagrams for the volcaniclastic rocks from the $M R U(A)$, the RCS and the LPT fms. (B) (after Verma and Armstrong-Altrin, 2013).

DF: Discriminant Functions. Pie charts represent the calculated probabilities for the set of samples to belong to each field taken into account in these diagrams.

Figure 9. Tectonic discrimination diagrams for the dacitic boulders of the RCS Fm. and the LPT Fm. (after Verma et al., 2013).

DF: Discriminant Functions. CA: Continental Arc; IA: Island Arc; Col: Collision; CR+OI: Continental Rift + Oceanic Island tectonic settings. Pie chart represents the calculated probabilities for the set of samples to belong to each field taken into account in the five discrimination diagrams. Shaded diagram: a posteriori determined inoperative diagram (continental arc field absent in this diagram).

Figure 10. Tera-Wasserburg diagrams for volcaniclastics rocks from the Luang Prabang Basin.

All the diagrams have been generated using Isoplot/Ex 3.00 (Ludwig, 2012).

A. General key for the Tera-Wasserburg diagrams.

B, C, D. Purple Claystone Fm.

E. Red Claystone Fm.

F, G, H. Luang Prabang Tuffite Fm.

I. Undifferentiated Red Claystone-Luang Prabang Tuffite Fm.

J. Mafic Rocks Unit. 
Figure 11. Geochronological diagrams for volcanic boulders sampled in the RCS Fm., the LPT Fm. and the Luang Prabang nappe (undifferentiated RCS-LPT fms.).

All the diagrams have been generated using Isoplot/Ex 3.00 (Ludwig, 2012). Error ellipses in the Tera-Wasserburg and Wetherill diagrams and boxes in the Tuff Zirc date diagrams are depicted at $1 \sigma$ level, but uncertainties on Tuff Zirc dates are given at the $2 \sigma$ level. Shaded ellipses and heavy grey boxes correspond to the analyses included in the calculation of the Tuff Zirc dates.

A. Dacitic boulder sampled in the RCS Fm.

B, C, D. Andesitic to dacitic boulders samples in the LPT Fm.

E. Andesitic boulder samples in the Luang Prabang nappe (undifferentiated RCS - LPT fms.).

Figure 12. Duration of the volcanism documented in the Luang Prabang Basin.

A. Simplified chart for the stratigraphy and volcanism of the Luang Prabang Basin. 1. Revised chronostratigraphic chart. 2. Duration of the volcanism documented in this basin.

B. Summary of the U-Pb/detrital and magmatic zircon dates available for the Luang Prabang Basin. U-Pb/detrital zircon dates correspond to the maximum depositional ages. Dates marked with a star correspond to samples discussed in Blanchard et al. (2013) and recalculated following the procedure described in section 3.2. for the sake of consistency. These dates are identical within uncertainties to those reported by Blanchard et al. (2013). The maximum depositional age reported for sample LP04 does not respect the 3 grain criterion adopted in this work, the strict application of this criterion give a maximum depositional date of $300.5 \pm 3.7$ Ma (see text for discussion). 
C. Radial plot (generated using DensityPlotter 6.3, Vermeesch, 2012) for the concordant dates obtained on volcaniclastic samples ranging between ca. $250 \mathrm{Ma}$ and ca. 215 Ma. Samples marked with a star correspond to those from Blanchard et al. (2013).

Figure 13. Tentative schematic geodynamic evolution model for the Triassic northern Indochina Block.

See text for explanation.

Figure 14. Tentative schematic paleogegraphic evolution model for the Triassic east Tethyan domain.

See text for explanation. The arrows (cartoon C) refer to the potential marine connections between the Luang Prabang Basin (as demonstrated by the occurrence of la Triassic marine fossils) and the residual Nan Uttaradit branch of the Paleotethys ocean.

\section{Tables}

Table 1. Main characteristics for the formations of the Luang Prabang Basin from literature data.

Table 2. Main petrographic features of the analyzed samples. 
Table 3. Detection limits and maximum depositional ages of volcaniclastic rocks from the Luang Prabang Basin.

\section{Appendices}

\section{Appendix 1}

Detection limits and uncertainties for the geochemical analyses.

\section{Appendix 2}

Supplementary data on the methodology for U-Pb/zircon geochronology.

Table S1. Comparison between the use of the probability of concordance and the percentage of concordance on detection limits and maximum depositional ages.

Table S2. Comparison between the TIMS age of the secondary 91500 standard zircon and measurements performed during the course of the analyses.

\section{Appendix 3}

Analytical results of whole rock geochemical analyses.

\section{Appendix 4}

Comparison of various tectonic discrimination diagrams. 


\section{Appendix 5}

Analytical results of LA-ICP-MS U-Pb/zircon dating.

\section{Vitae}

Camille Rossignol recently completed his $\mathrm{PhD}$ focused on the Triassic geodynamic evolution of the East Tethyan Domain at the Rennes 1 University (defended in December, 2014), supervised by Sylvie Bourquin and Marie-Pierre Dabard. The present study is part of his $\mathrm{PhD}$ dissertation.

Sylvie Bourquin, coordinator of the INSU/CNRS INTERRVIE program supporting the expedition, is CNRS Research Director at Géosciences Rennes, Rennes 1 University. She is a specialist in sedimentology and in sequence stratigraphy correlations of continental deposits from field and subsurface (from core and well-log analysis) data. She develops associations between specialists in sedimentology, tectonics, geochronology and paleontology to reconstruct paleoenvironments at different space and time scales and to test the impact of geodynamic and climate on the stratigraphic record and sediment preservations. She has mainly focused her research on Permian and Triassic series in the western Tethyan domain (Europe, North Africa).

Marie-Pierre Dabard is permanent Associate Professor at the University of Rennes 1. She is a sedimentologist, specialist in clastic sediments. Her work has focused on research of mineralogical and geochemical indicators of source areas in paleogeographic reconstructions, particularly in West European ancient belts (Cadomian belt and 
Hercynian belt). Currently her interests include the evolution of the North Gondwana margin (Europe and Morocco) during the lower Palaeozoic (environmental reconstructions and identification of the sea level fluctuations).

Erwan Hallot is permanent Associate Professor at the University of Rennes 1 . He is a magmatic petrologist, specialized in the petro-geochemical characterization of intrusive and volcanic rocks from the field to the mineral scales, and in the modeling, especially via laboratory-scaled experiments, of some of the physical processes involved during the production, the transport and/or the emplacement of terrestrial magma.

Thierry Nalpas is permanent Associate Professor at the University of Rennes 1 . He is a specialist on the interaction between sedimentation and deformation, from outcrops, subsurface data and analogic models.

Marc Poujol is permanent Associate Professor at the Rennes 1 University since 2006. He is specialized in $\mathrm{U}-\mathrm{Th}-\mathrm{Pb}$ geochronology and isotope geochemistry. His main research topic was initially dedicated to the study of crustal growth in Southern Africa during the Archean. He now applies the in-situ U-Th-Pb laser ablation ICP-MS dating technique to topics dealing mostly with the timing of fluid circulation in metamorphic, mineralized and/or deformed terranes. 


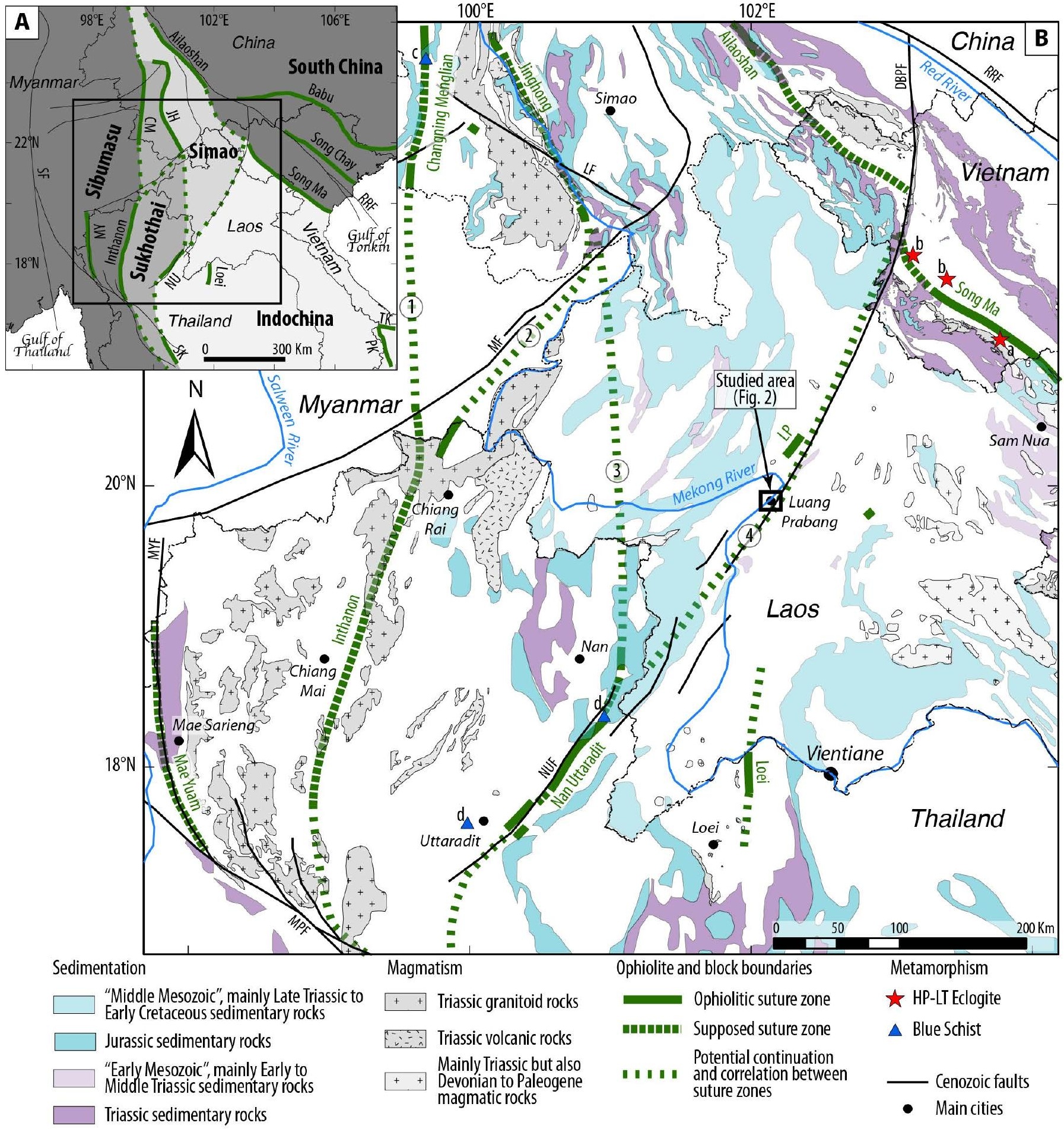





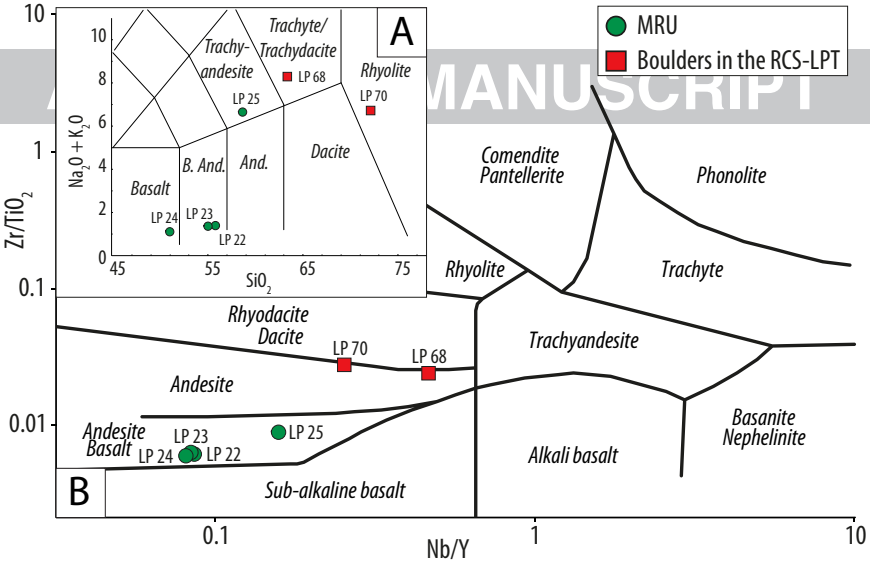




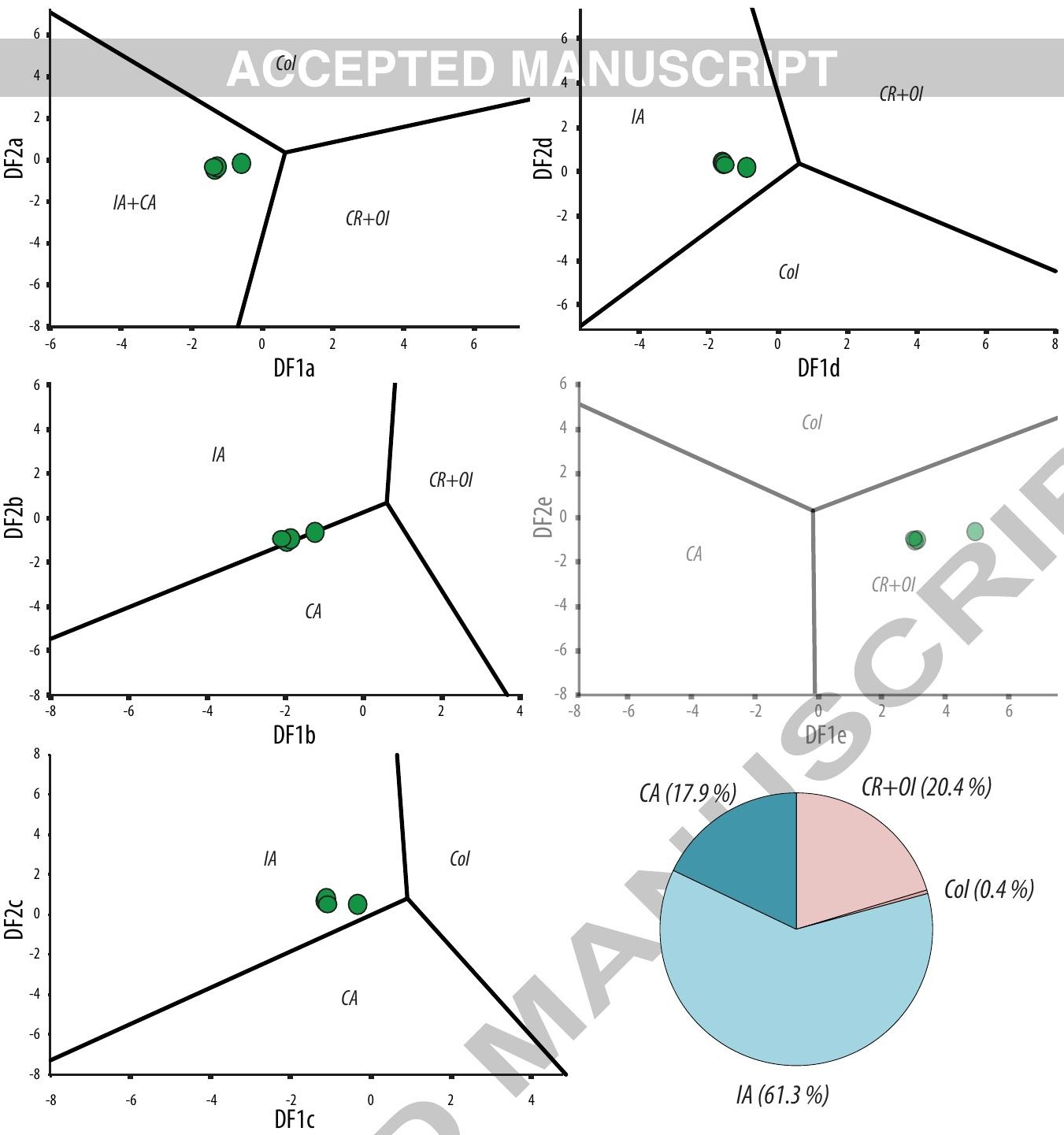



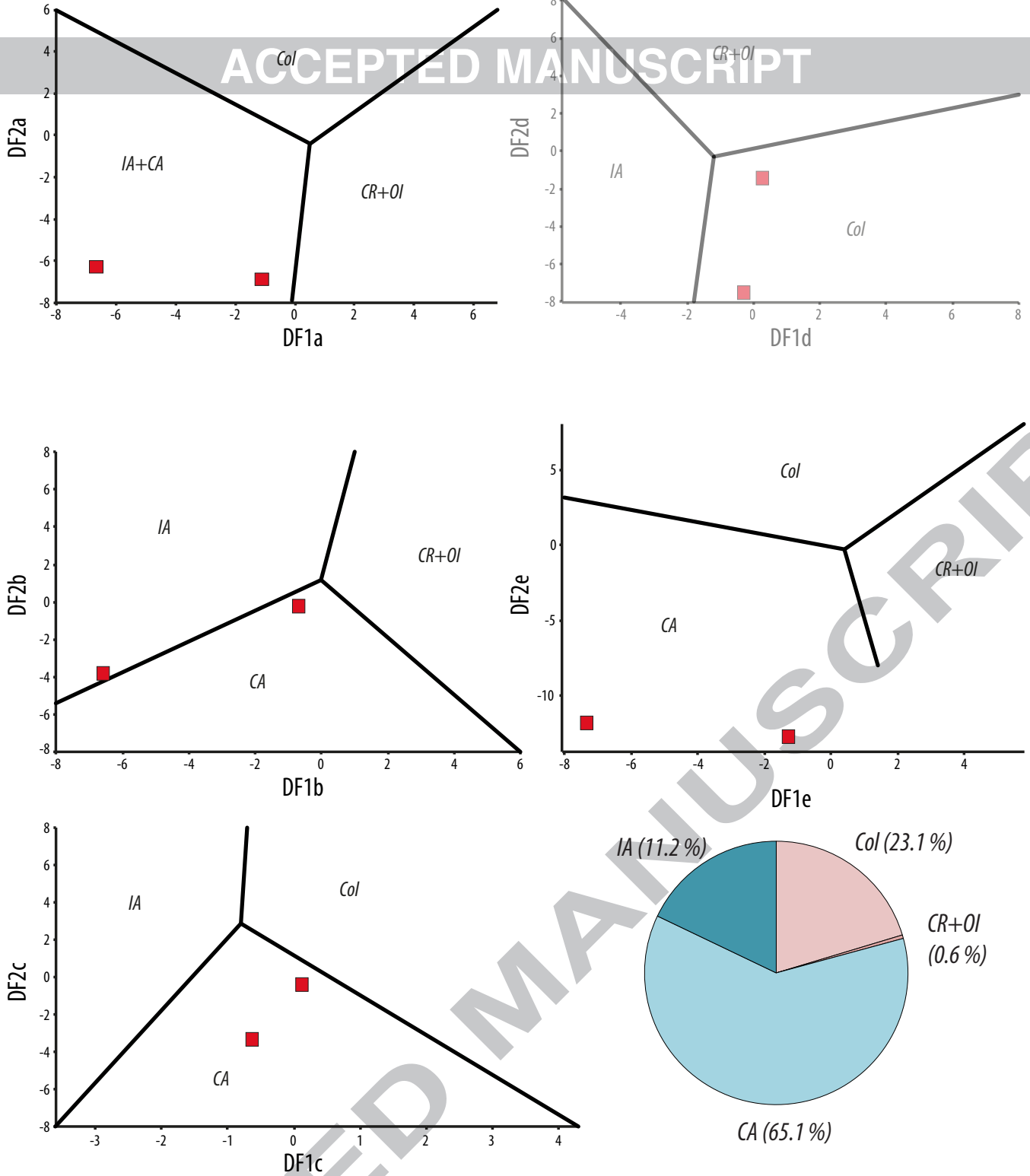
Error ellipse of analysis with probability of concordance $\geq 10 \%$, depicted at $1 \sigma$ level. Analyses with probability of

concordance $<10 \%$ are not shown in diagrams B to J

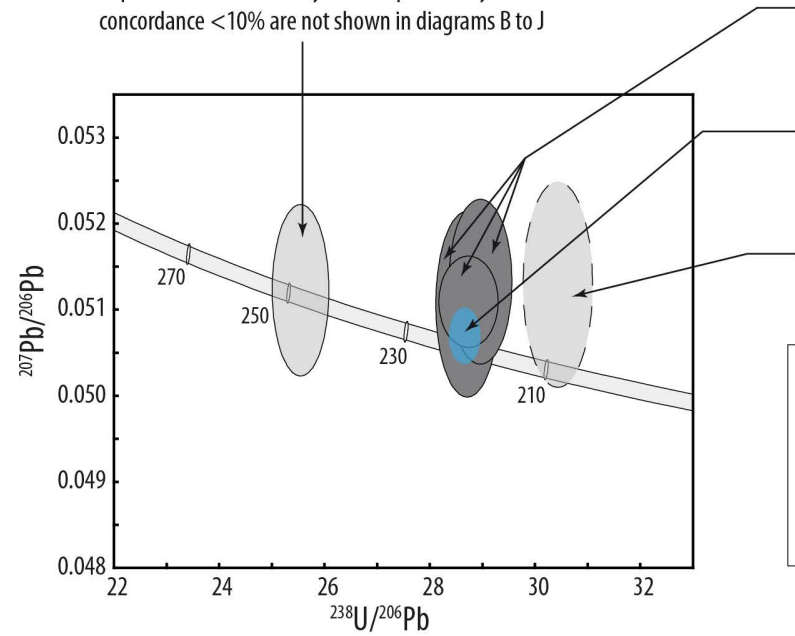

Error ellipses of analyses with probability of concordance $\geq 10 \%$ used for the maximum depositional age calculation, depicted at $1 \sigma$ level

Weighted mean error ellipse of at least 3 grains corresponding to the maximum depositional age, depicted at 20 level

Error ellipse of analysis with probability of concordance $\geq 10 \%$ younger than the maximum depositional age, interpreted as the result of $\mathrm{Pb}$ loss, depicted at 10 level

\section{Sample: Age $\pm 2 \sigma$ error (uncertainties on decay constants included)} $\mathrm{N} / \mathrm{N}_{\mathrm{a}} / \mathrm{N}_{z i}$ : number of analyses used to calculate the maximum depositional age/ total number of analyses/total number of zircon grains analyzed MSWD: for concordance and equivalence

Prob.: Probability for concordance and equivalence

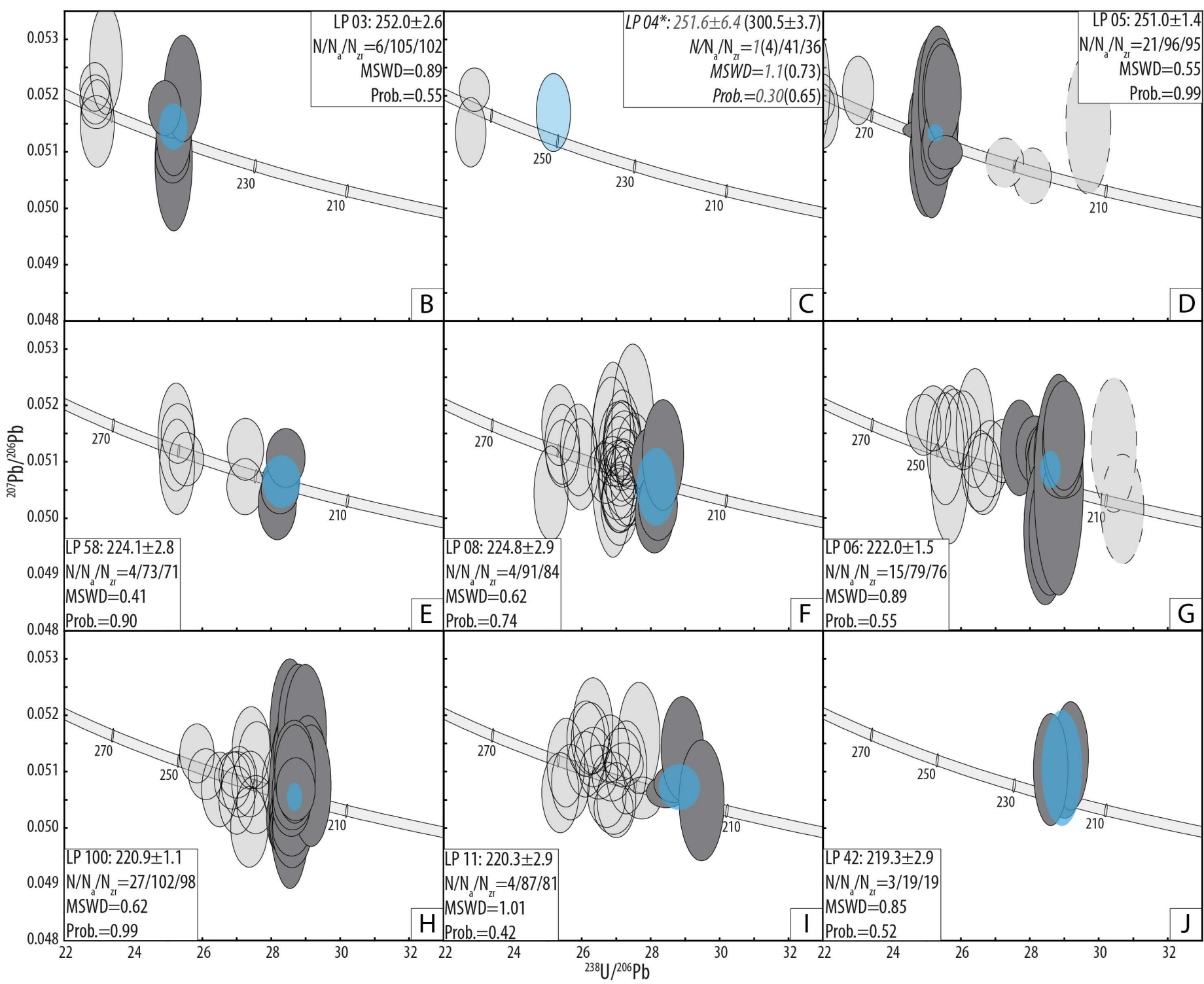




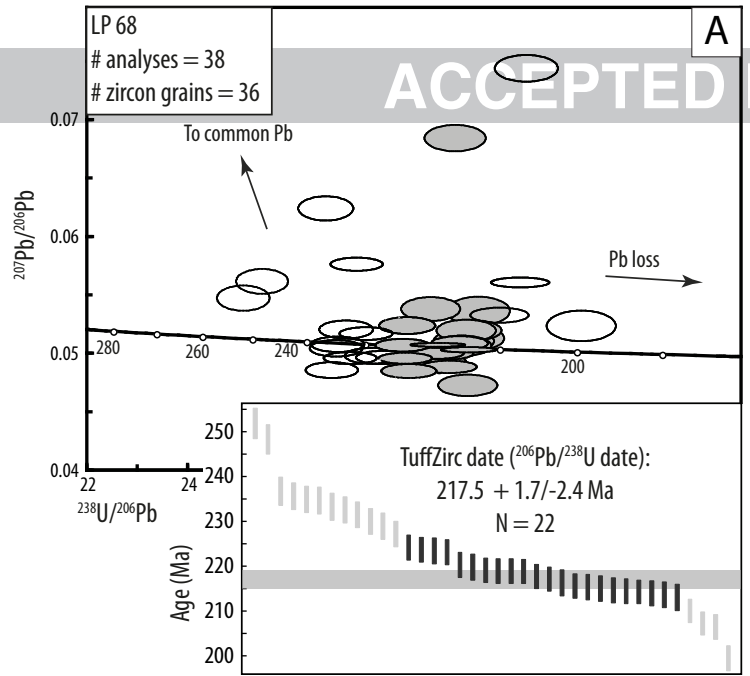

을
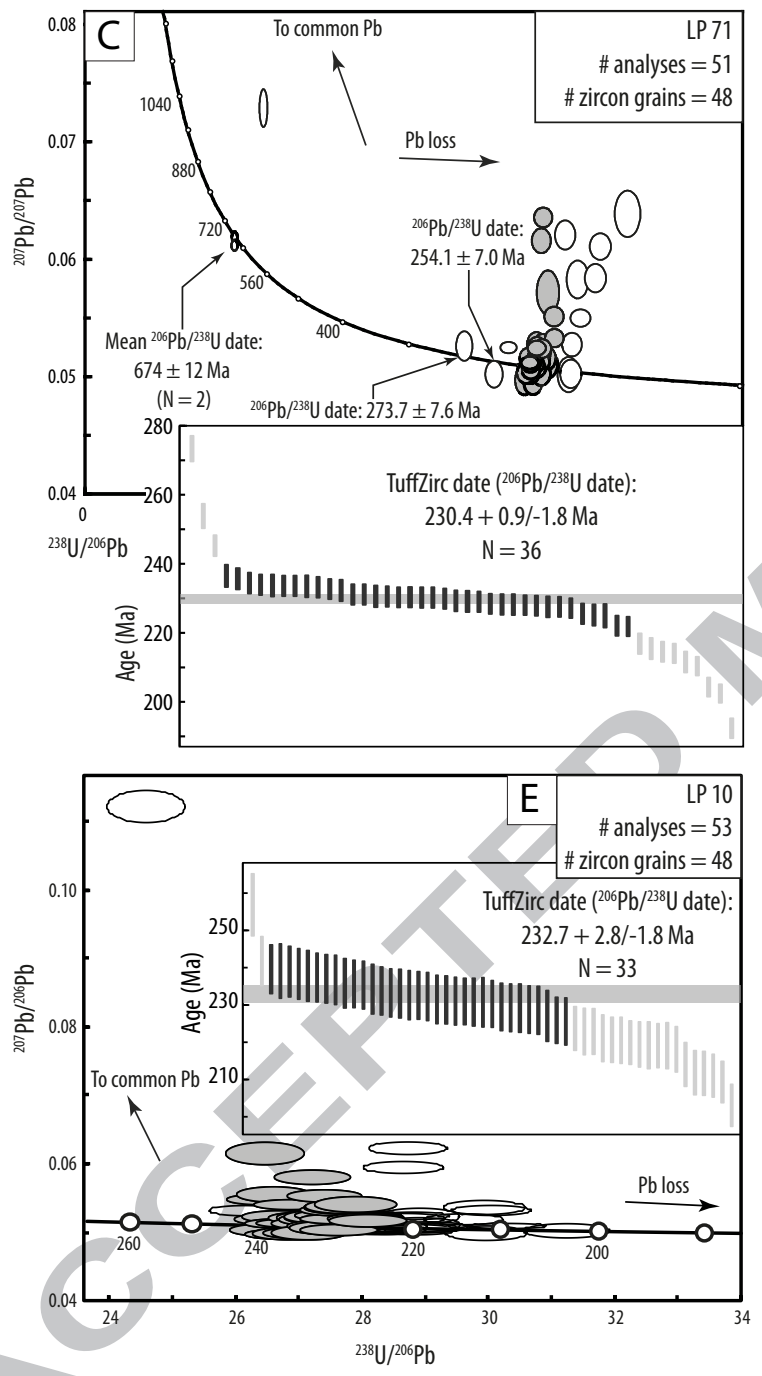
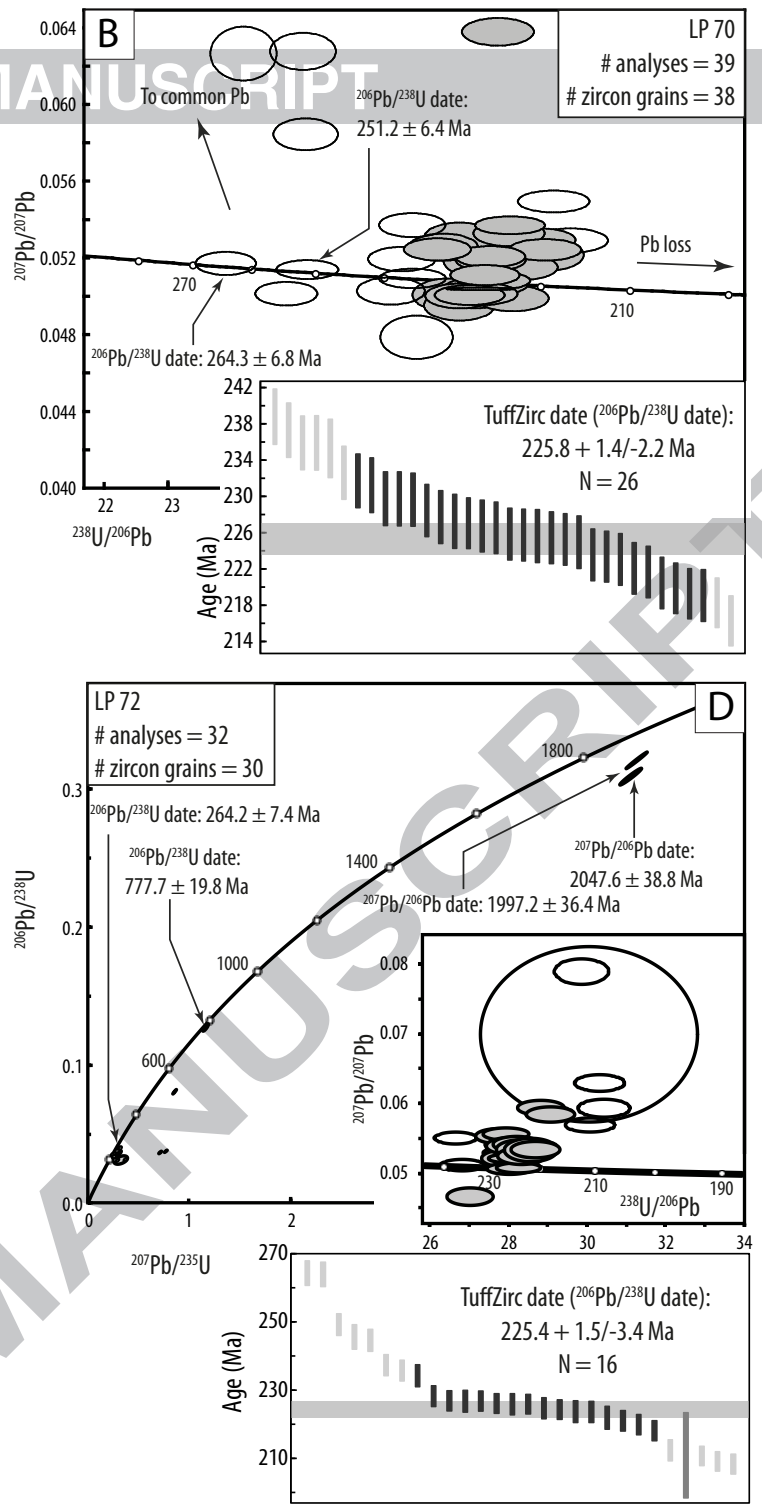


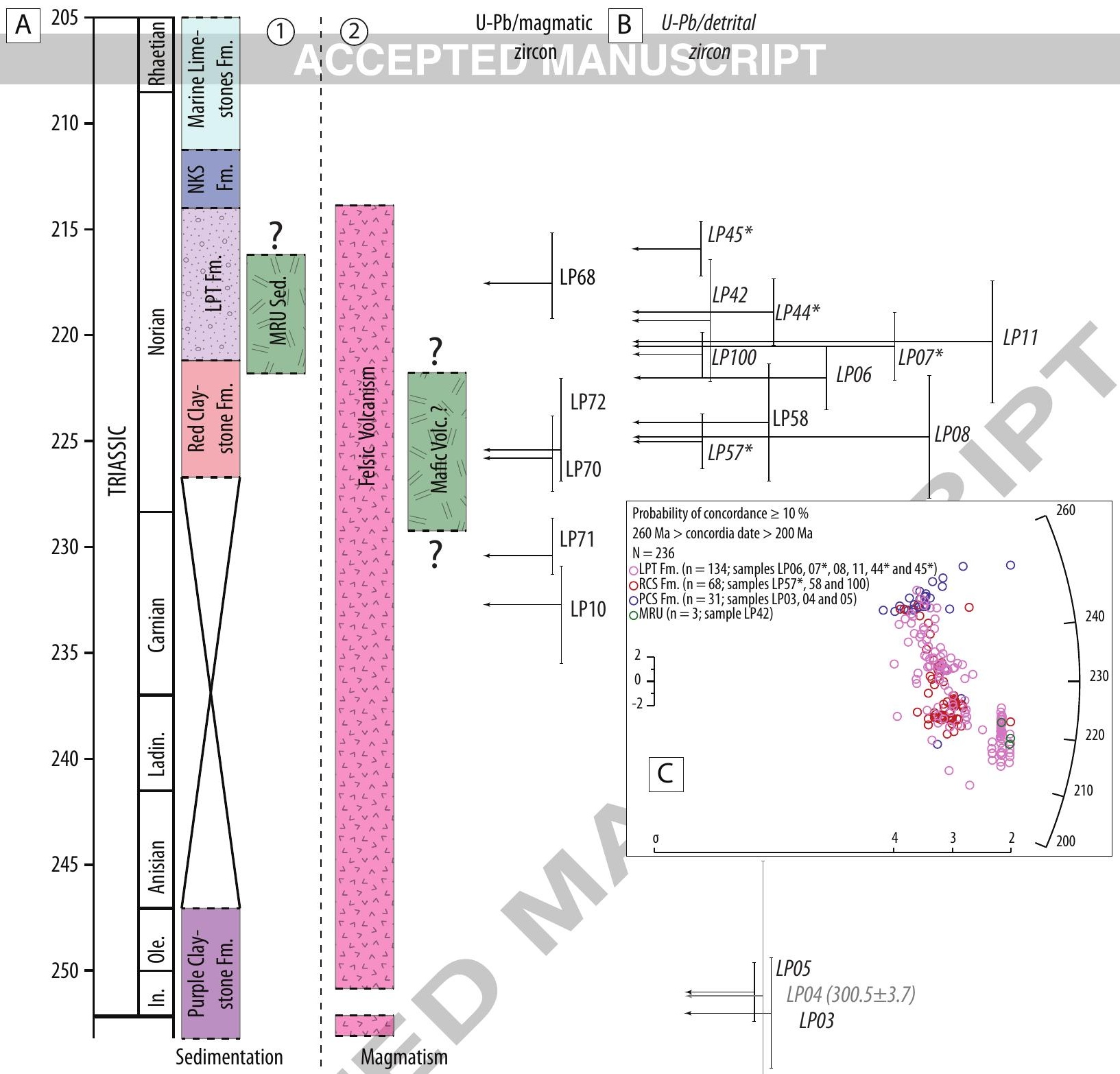



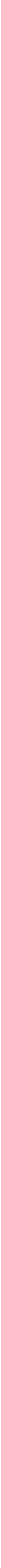


\section{A}

$\sim 305-250 \mathrm{Ma}$ Late Carboniferous -

Permian

\section{B}

$\sim 250-225 \mathrm{Ma}$ Early Triassic Late Triassic (Norian)

\section{C}

$\sim 225$ - $215 \mathrm{Ma}$ Late Triasic (Norian)

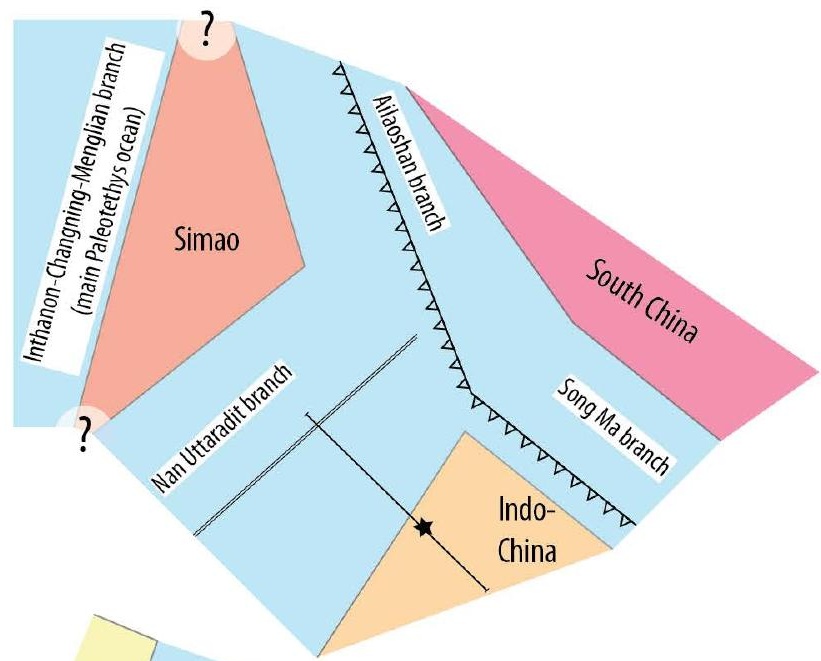


Table 1. Main characteristics for the formations of the Luang Prabang Basin from literature data.

\begin{tabular}{|c|c|c|c|c|}
\hline $\begin{array}{c}\text { Formation } \\
\text { (Fm.) }\end{array}$ & $\begin{array}{l}\text { Depositional } \\
\text { environment }\end{array}$ & Fossil content & Geochronological data & Inferred depositional age \\
\hline $\begin{array}{c}\text { Marine } \\
\text { Limestone Fm. } \\
\text { (ML Fm.) }\end{array}$ & Marine environment & $\begin{array}{l}\text { Cypridodella sp. conodont } \\
\text { (Blanchard et al., 2013) }\end{array}$ & & $\begin{array}{l}\text { Norian (Blanchard et al., } \\
\text { 2013) }\end{array}$ \\
\hline $\begin{array}{c}\text { Nam Khan } \\
\text { Sandstone Fm. } \\
\text { (NKS Fm.) }\end{array}$ & $\begin{array}{l}\text { Bed-load fluvial } \\
\text { system }\end{array}$ & & & $\begin{array}{c}\text { Norian (Blanchard et al., } \\
\text { 2013) }\end{array}$ \\
\hline $\begin{array}{l}\text { Luang Prabang } \\
\text { Tuffite Fm. } \\
\text { (LPT Fm.) }\end{array}$ & $\begin{array}{l}\text { Alluvial fan and/or } \\
\text { proximal braided } \\
\text { river }\end{array}$ & & $\begin{array}{l}\text { Maximum depositional } \\
\text { ages: } 220.7 \pm 1.0 ; 219.0 \pm \\
\text { 1.2; } 216.2 \pm 1.1 \mathrm{Ma}(\mathrm{U}- \\
\text { Pb/zircon; Blanchard et al., } \\
\text { 2013). } \\
\end{array}$ & $\begin{array}{c}\text { Norian (Blanchard et al., } \\
\text { 2013) }\end{array}$ \\
\hline $\begin{array}{l}\text { Red Claystone } \\
\text { Fm. (RCS Fm.) }\end{array}$ & $\begin{array}{l}\text { Alluvial plain to } \\
\text { braided river } \\
\text { (Blanchard et al., } \\
\text { 2013) } \\
\end{array}$ & $\begin{array}{c}\text { Dicynodont remains preliminarily } \\
\text { identified as a kannemeyeriiform } \\
\text { (Stahleckeria or a close relative, } \\
\text { Blanchard et al., 2013). }\end{array}$ & $\begin{array}{c}\text { Maximum depositional age: } \\
224.9 \pm 1.0 \mathrm{Ma}(\mathrm{U}- \\
\mathrm{Pb} / \text { zircon; Blanchard et al., } \\
\text { 2013) }\end{array}$ & $\begin{array}{l}\text { Norian (Blanchard et al., } \\
\text { 2013) }\end{array}$ \\
\hline $\begin{array}{l}\text { Purple } \\
\text { Claystone Fm. } \\
\text { (PCS Fm.) }\end{array}$ & $\begin{array}{l}\text { Braided river } \\
\text { environment to } \\
\text { alluvial plain } \\
\text { (Bercovici et al., } \\
\text { 2012) }\end{array}$ & $\begin{array}{l}\text { Dicynodont remains attributed to } \\
\text { "Dicynodon sensu lato" (Battail, } \\
\text { 2009); chroniosuchian (Bercovici et } \\
\text { al., 2012) }\end{array}$ & & $\begin{array}{l}\text { Late Permian (Battail, } \\
\text { 2009) }\end{array}$ \\
\hline $\begin{array}{l}\text { Limestone and } \\
\text { Sandstone Fm. } \\
\text { (LS Fm.) }\end{array}$ & $\begin{array}{c}\text { Coastal environment } \\
\text { (Bercovici et al., } \\
\text { 2012) } \\
\end{array}$ & $\begin{array}{l}\text { Paleoflora, Pseudotirolites sp. } \\
\text { ammonoid (Bercovici et al., 2012) }\end{array}$ & & $\begin{array}{l}\text { Changhsingian (upper } \\
\text { late Permian, Bercovici } \\
\text { et al., 2012) }\end{array}$ \\
\hline
\end{tabular}


Table 2. Main petrographic features of the analyzed samples.

\begin{tabular}{|c|c|c|}
\hline Sample & Analyse(s) & Petrography \\
\hline \multicolumn{3}{|c|}{ Mafic Rock Unit } \\
\hline LP 22 & Geochemistry & $\begin{array}{l}\text { Porphyritic basalt. } \\
\text { Slightly weathered, euhedral plagioclase and zoned clinopyroxene phenocrysts with sector twinning. Euhedral } \\
\text { opaque minerals. Secondary chlorite, quartz (quartz veins), carbonate (calcite) and epidote. Groundmass with } \\
\text { plagioclase and opaque minerals microlites. }\end{array}$ \\
\hline LP 23 & Geochemistry & $\begin{array}{l}\text { Porphyritic basalt. } \\
\text { Slightly weathered, euhedral plagioclase and large clinopyroxene phenocrysts. Euhedral opaque minerals. } \\
\text { Secondary chlorite with polycrystalline quartz and calcite (numerous quartz and calcite veins). Groundmass } \\
\text { with plagioclase microlites. }\end{array}$ \\
\hline LP 24 & Geochemistry & $\begin{array}{l}\text { Porphyritic trachytic Basalt. } \\
\text { Mainly slightly weathered, euhedral plagioclase, rare alkaline feldspar and a few clinopyroxene phenocrysts. } \\
\text { Secondary chlorite, cryptocrystalline to polycrystlline quartz and calcite (quartz and calcite veins). Groundmass } \\
\text { rich in plagioclase microlites. }\end{array}$ \\
\hline LP 25 & Geochemistry & $\begin{array}{l}\text { Porphyritic microgabbro. } \\
\text { Weathered, sub-euhedral plagioclase and clinopyroxene phenocrysts. Xenomorphic quartz rich in inclusion, } \\
\text { among which apatite needles. Secondary chlorite, quartz and calcite occurring mainly as veins. Secondary } \\
\text { opaque minerals associated with titanite. }\end{array}$ \\
\hline LP 32 & Geochemistry & $\begin{array}{l}\text { Fine-grained tuffaceous arenite. } \\
\text { Angular, sericitized feldspar, among which plagioclase. Chlorite, a few (sometimes polycrystalline) quartz } \\
\text { grains, amiboidal mineral. }\end{array}$ \\
\hline LP 34 & Geochemistry & $\begin{array}{l}\text { Coarse-grained tuffaceous arenite. } \\
\text { Weathered volcaniclasts with various textures (microlitic, porphyritic with a variable amount of phenocrysts). } \\
\text { Silty lithic fragments. Strongly weathered monocrystalline feldspar and greenish clinopyroxene (aegyrine } \\
\text { augite). Rounded quartz, chlorite, opaque minerals. }\end{array}$ \\
\hline LP 35 & Geochemistry & $\begin{array}{l}\text { Coarse-grained tuffaceous arenite. } \\
\text { Similar to sample LP } 34 .\end{array}$ \\
\hline LP 38 & Geochemistry & $\begin{array}{l}\text { Fine-grained tuffite arenite. } \\
\text { Weathered, sub-rounded to sub-angular volcaniclast displaying microlitic or trachytic textures. Weathered, } \\
\text { sub-rounded to angular monocrystalline feldspar among which plagioclase, and pyroxene. Quartz grain, } \\
\text { sometimes with undulatory extinction. Calcite, epidote, chlorite, opaque minerals. Calcite veins. }\end{array}$ \\
\hline LP 40 & Geochemistry & $\begin{array}{l}\text { Well-sorted tuffaceous arenite. } \\
\text { Sub-angular to sub-rounded elements. Weathered volcaniclast displaying microlitic and/or porphyritic texture. } \\
\text { Sub-rounded pyroxene, sometimes slightly greenish (aegyrine augite). Monocrystalline weathered feldspar } \\
\text { (among which plagioclase), partly replaced by calcite, monocrystalline calcite, quartz and opaque minerals, } \\
\text { chlorite, epidote. }\end{array}$ \\
\hline LP 41 & Geochemistry & $\begin{array}{l}\text { Coarse-grained tuffite arenite. } \\
\text { Weathered angular to sub-rounded volcaniclasts displaying microlitic porphyritic textures with strongly } \\
\text { sericitized feldspar phenocryst. Composite lithic fragments (reworked volcaniclast embedded within a silty } \\
\text { matrix). Silty and calcite rich lithic fragments. Monocrystalline weathered pyroxene and feldspar, among which } \\
\text { plagioclase. Chlorite. }\end{array}$ \\
\hline LP 42 & $\begin{array}{l}\text { U-Pb/zircon } \\
\text { Geochemistr }\end{array}$ & $\begin{array}{l}\text { Tuffaceous arenite. } \\
\text { Volcaniclasts with microlitic or porphyritic textures (with plagioclase as phenocrysts). Monocrystalline, } \\
\text { weathered plagioclase and a few alkaline feldspars. Sedimentary silty lithic fragments, chlorite, quartz, epidote, } \\
\text { opaque minerals. }\end{array}$ \\
\hline LP 66 & Geochemistry & $\begin{array}{l}\text { Tuffaceous arenite. } \\
\text { Slightly greenish, sub-rounded to sub-angular clinopyroxene (aegyrine augite) embedded in rounded to sub- } \\
\text { rounded porphyritic volcaniclasts or occurring as monocrystalline volcaniclasts. Sedimentary, silty to sandy, } \\
\text { lithic fragment. Matrix rich in opaque minerals. }\end{array}$ \\
\hline \multicolumn{3}{|c|}{ Purple Claystone Formation } \\
\hline LP 03 & U-Pb/zircon & $\begin{array}{l}\text { Tuffaceous arenite } \\
\text { Various, mostly sub-rounded lithic fragments: microgranular quartz clasts, microcrystalline quartz clasts partly } \\
\text { calcitized, clasts with various igneous textures (microlitic to trachytic texture, often altered and weathered, or } \\
\text { granular texture with quartz and strongly calcitized feldspar). Altered monocrystalline feldspars, plagioclases. } \\
\text { Polycrystalline quartz grains. Rounded to sub-angular calcareous fragments with various textures (micritic to } \\
\text { sparitic), sometimes encasing bioclastic elements. Rounded silicic sedimentary fragments. Opaque minerals, } \\
\text { epidote, zircon. Calcite vein. }\end{array}$ \\
\hline LP 04 & U-Pb/zircon & $\begin{array}{l}\text { Tuffaceous arenite. } \\
\text { Thin section not realized. }\end{array}$ \\
\hline LP 05 & U-Pb/zircon & $\begin{array}{l}\text { Tuffaceous arenite } \\
\text { Various lithic fragments: rounded clasts of cryptocrystalline quartz, microgranular quartz clasts, clasts with } \\
\text { various magmatic textures (porphyritic with feldspars among which plagioclases, strongly altered trachytic or } \\
\text { glass-rich microlitic textures, spherolitic texture). Calcite in replacement of other minerals or coating other } \\
\text { elements (calcrete). Calcite veins. Monocristalline feldspars, epidote, zircon. }\end{array}$ \\
\hline \multicolumn{3}{|c|}{ Red Claystone Formation } \\
\hline LP 58 & U-Pb/zircon & $\begin{array}{l}\text { Tuffaceous arenite } \\
\text { Monocrystalline quartz grain, sometimes of rhyolitic type (e.g. with embayment against volcanic groundmass } \\
\text { or sedimentary matrix). Pseudomorphs of hydroxyl-rich mineral filled by opaque minerals. Polycristalline quartz } \\
\text { grain, altered feldspar (among which plagioclase, commonly replaced by calcite), biotite, muscovite, micritic to }\end{array}$ \\
\hline
\end{tabular}


sparitic calcite fragments, red claystone fragments. Apatite, zircon, tourmaline.

Laminated fine-grained quartz to lithic wacke.

LP 59 Geochemistry Mainly fine-grained rounded quartz grains displaying sometime embayment against the groundmass/matrix (rhyolitic quartz). Rounded polycrystalline quartz grains and intra-formational lithic fragments. Opaque minerals. Silty matrix.

Tuffaceous arenite.

Rounded to angular and variously sized (millimeter to centimeter) lithic fragments. Initial textures overprinted

LP 100 U- Pb/zircon calcitization, but microgranular (altered feldspars, quartz) clasts and volcaniclasts with subangular shape and microlitic to trachytic texture are recognizable. Rounded sedimentary elements and monocrystalline feldspars, zircon. Areas with undulant extinction, interpreted as silicified area. Minute grained matrix with opaque minerals, calcite, altered feldspars (among which plagioclases) and argillaceous minerals. Trachytic porphyritic andesite.

LP $68 \quad \mathrm{U}$-Pb/zircon Plagioclase, phenocrysts, clusters of opaque minerals representing pseudmorph after a Fe, Mg rich mineral Geochemistry (amphibole, possibly hornblende according to its shape), allanite, titatnite, zircon, apatite, euhedral opaque minerals. Groundmass with opaque mineral, plagioclase and sanidine microlites, apatite microphenocryst.

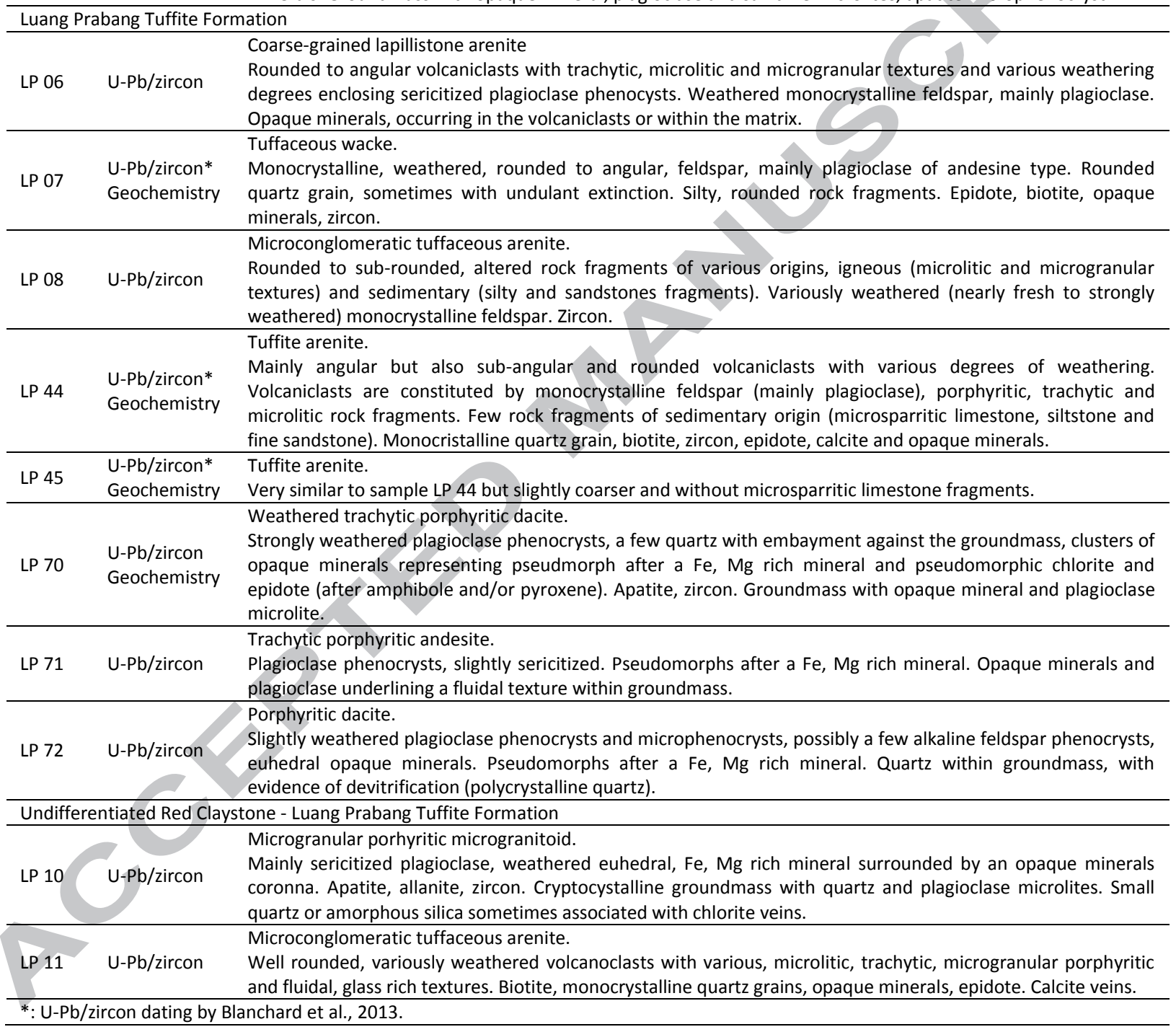


Table 3. Detection limits and maximum depositional ages of volcaniclastic rocks from the Luang Prabang Basin.

\begin{tabular}{|c|c|c|c|c|c|c|c|c|c|c|c|c|}
\hline \multirow{3}{*}{ Sample } & \multirow{3}{*}{$\mathrm{N}_{\mathrm{a}}$} & \multirow{3}{*}{$\mathrm{N}_{\mathrm{zr}}$} & \multicolumn{10}{|c|}{ Probability of concordance $\geq 10 \%$, decay constants errors included } \\
\hline & & & \multirow[b]{2}{*}{$\mathrm{N}$} & \multicolumn{4}{|c|}{ Detection limits (\%) } & \multicolumn{5}{|c|}{ Maximum depositional age } \\
\hline & & & & $\mathrm{DL}_{1(\mathrm{pL}=0.5)}$ & $\mathrm{DL}_{1(\mathrm{pL}=0.95)}$ & $\mathrm{DL}_{3(\mathrm{pL}=0.5)}$ & $\mathrm{DL}_{1(\mathrm{pL}=0.95)}$ & $\begin{array}{l}\text { concordia } \\
\text { age }\end{array}$ & $\pm(2 \sigma)$ & $\mathrm{n}$ & MSWD & Probability \\
\hline \multicolumn{13}{|c|}{ Mafic Rock Unit } \\
\hline LP42 & 19 & 19 & 4 & 15.9 & 52.7 & 61.5 & 90.3 & 219.3 & 2.9 & 3 & 0.85 & 0.52 \\
\hline \multicolumn{13}{|c|}{ Purple Claystone Formation } \\
\hline LP03 & 105 & 102 & 25 & 2.7 & 11.3 & 10.6 & 23.2 & 252.0 & 2.6 & 6 & 0.89 & 0.55 \\
\hline LP04 & 41 & 36 & 7 & 9.4 & 34.8 & 36.5 & 65.9 & 300.5 & 3.7 & 4 & 0.73 & 0.65 \\
\hline LP05 & 96 & 95 & 39 & 1.8 & 7.4 & 6.8 & 15.3 & 251.0 & 1.4 & 21 & 0.55 & 0.99 \\
\hline \multicolumn{13}{|c|}{ Red Claystone Formation } \\
\hline LP58 & 73 & 71 & 24 & 2.8 & 11.7 & 11.0 & 24.0 & 224.1 & 2.8 & 4 & 0.41 & 0.90 \\
\hline LP100 & 102 & 98 & 40 & 1.7 & 7.2 & 6.7 & 15.0 & 220.9 & 1.1 & 27 & 0.62 & 0.99 \\
\hline \multicolumn{13}{|c|}{ Luang Prabang Tuffite Formation } \\
\hline LP06 & 79 & 76 & 28 & 2.4 & 10.1 & 9.5 & 20.9 & 222.0 & 1.5 & 15 & 0.97 & 0.51 \\
\hline LP08 & 91 & 84 & 38 & 1.8 & 7.6 & 7.0 & 15.7 & 224.8 & 2.9 & 4 & 0.62 & 0.74 \\
\hline \multicolumn{13}{|c|}{ Undifferentiated Red Claystone - Luang Prabang Tuffite formations } \\
\hline LP11 & 87 & 81 & 26 & 2.6 & 10.9 & 10.2 & 22.3 & 220.3 & 2.9 & 4 & 1.01 & 0.42 \\
\hline \multicolumn{13}{|c|}{$\begin{array}{l}\mathrm{N}_{\mathrm{a}} \text { : number of analyses per sample; } \mathrm{N}_{\mathrm{zr}} \text { : number of zircon grain analyzed per sample; N: number of concordant zircon grain; n: } \\
\text { number of analyses used to calculate the maximum deposition age; } \mathrm{DL}_{1} \text { : detection limit for at least one grain; DL } \mathrm{L}_{3} \text { : detection limit for } \\
\text { at least three grains; } \mathrm{pL} \text { : probability level assigned to the detection limits; MSWD: mean square of weighted deviates. The MSWD and } \\
\text { the probability given for the concordia ages are for both concordance and equivalence. }\end{array}$} \\
\hline
\end{tabular}


Graphical abstract

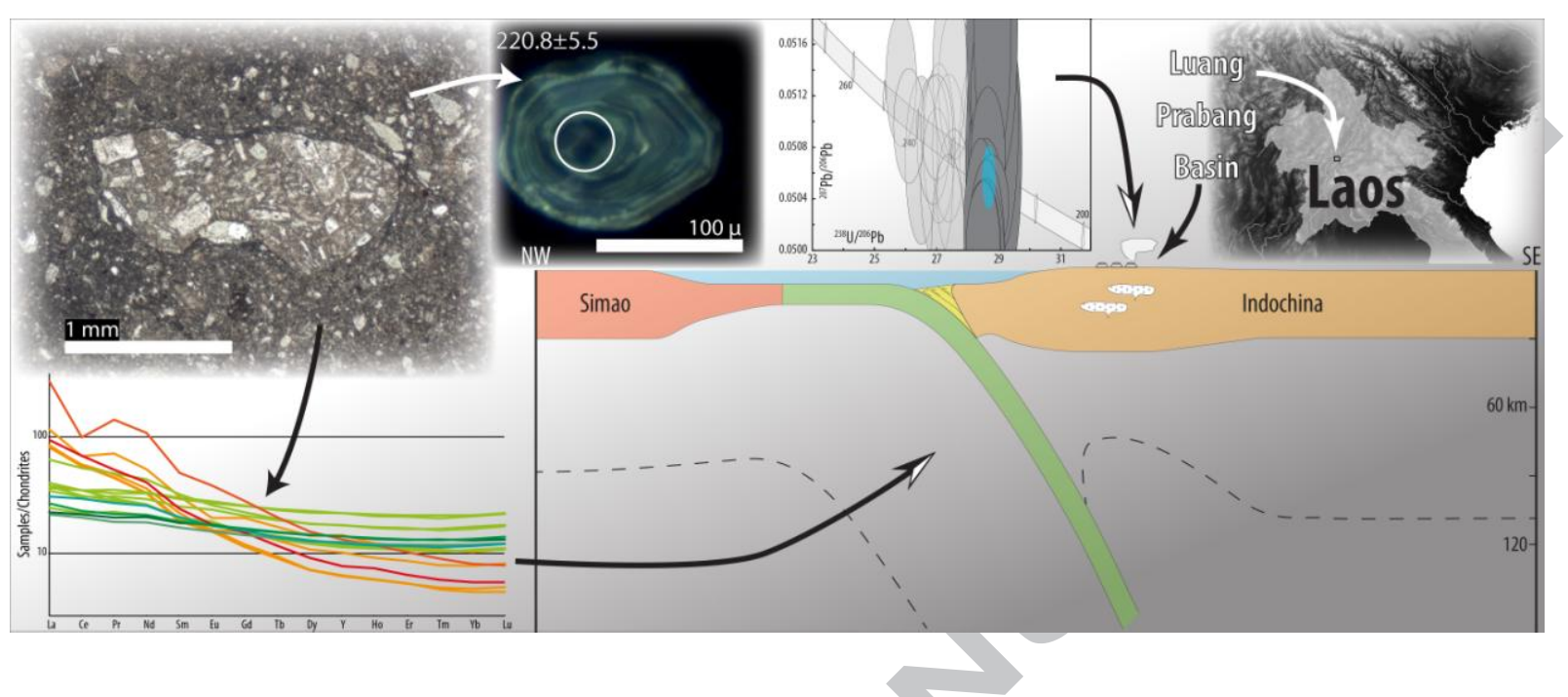




\section{Highlights}

- Unexpected Triassic volcanic arc in northwest Laos

- Continuous volcanic activity from the Early up to the Late Triassic (Norian)

- Arc located on the western margin of the Indochina block

- Related to an east dipping subduction of the "Nan Uttaradit - Luang Prabang slab" 